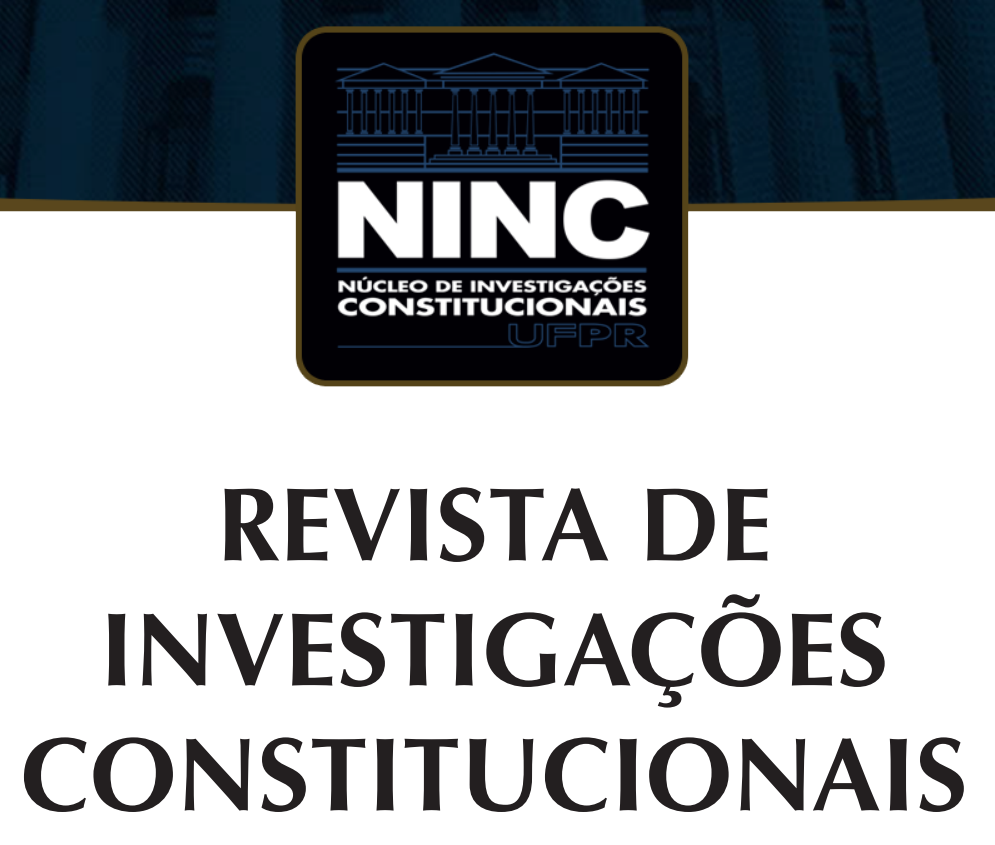

JOURNAL OF CONSTITUTIONAL RESEARCH

vol. 7 | n. 1 | janeiro/abril 2020 | ISSN 2359-5639 | Periodicidade quadrimestral Curitiba | Núcleo de Investigações Constitucionais da UFPR | www.ninc.com.br 


\title{
Força autoritativa, influência persuasiva ou qualquer coisa: 0 que é um precedente para o Supremo Tribunal Federal?**
}

\section{Authoritative force, persuasive influence or anything: what counts as a legal precedent for the Brazilian Federal Supreme Court?}

\author{
FERNANDO LEAL ${ }^{\text {, ** }}$ \\ 'Fundação Getúlio Vargas - FGV (Brasil) \\ fernando.leal@fgv.br \\ https://orcid.org/0000-0001-9004-5904 \\ Recebido/Received: 19.12.2019 / December 19 1t $^{\text {t }} 2019$ \\ Aprovado/Approved: 30.04 .2020 / April 30 3020
}

\section{Resumo}

O presente trabalho oferece respostas possíveis para a pergunta "o que é um precedente para o Supremo Tribunal Federal?". Para além dos debates teóricos a respeito das razões que sustentam a vinculação da solução de casos atuais a casos precedentes, o artigo apresenta sete diferentes possibilidades de resposta para a questão posta, todas elas consideradas, em alguma medida, problemáticas para o estabelecimento de uma prática adequada de precedentes na corte.

Palavras-chave: Precedentes; Supremo Tribunal Federal; Razões autoritativas; Obiter dicta; Ratio decidend Ministrocracia.

\section{Abstract}

This paper aims to propose possible answers to the question "What is a precedent for the Brazilian Federal Supreme Court?". Beyond theoretical debates regarding the reasons that support the binding of the solutions of current cases to previous cases (precedents), the text presents seven different possibilities for answering that question. All of which might be considered, to some extent, problematic for establishing an adequate implementation of precedents in court.

Keywords: Precedents; Brazilian Federal Supreme Court; Authoritative reasons; Obiter dicta; Ratio decidendi; Ministrocracy.

Como citar esse artigo/How to cite this article: LEAL, Fernando. Força autoritativa, influência persuasiva ou qualquer coisa: o que é um precedente para o Supremo Tribunal Federal? Revista de Investigações Constitucionais, Curitiba, vol. 7, n. 1, p. 205-236, jan./abr. 2020. DOI: 10.5380/rinc.v7i1.70888.

* Por comentários a versões anteriores deste trabalho, agradeço a Ana Paula de Barcellos, Fábio Perin Shecaira e a todos os participantes do seminário PósDebate, da Universidade de São Paulo, realizado no dia 23/4/2020.

** Professor Pesquisador Adjunto da Fundação Getúlio Vargas Direito Rio - FGV (Rio de Janeiro-RJ, Brasil). Professor e coordenador do Programa de Pós-Graduação Stricto Sensu em Direito da Regulação da Escola de Direito do Rio de Janeiro da Fundação Getúlio Vargas - FGV (Rio de Janeiro-RJ, Brasil). Doutor em Direito pela Christian-Albrechts-Universität zu Kiel (Kiel-SH, Alemanha). Doutor e mestre em Direito Público pela Universidade do Estado do Rio de Janeiro - UERJ (Rio de Janeiro-RJ, Brasil). Graduado em Direito pela Universidade do Estado do Rio de Janeiro - UERJ (Rio de Janeiro-RJ, Brasil). E-mail: fernando.leal@fgv.br. 


\section{SUMÁRIO}

1. Introdução. 2. A transcrição de ementas e a transferência dos ônus de prova e de argumentação para os destinatários da decisão. 3. O apelo a obiter dicta. 4. A aproximação meramente temática. 5. $O$ recurso a teses gerais desvinculadas do caso decidido. 6. Toda decisão é um precedente "do Supremo"? 7. Um precedente impossível. 8. Quando a corte acerta: acaso ou uso estratégico? 9. Conclusão. 10. Referências.

\section{INTRODUÇÃO}

"O que define um precedente?" é uma pergunta de resposta não evidente. Se a sua força de vinculação se dá por razões substantivas ou autoritativas; se um precedente se estrutura como uma regra e exige, assim, raciocínio prioritariamente subsuntivo em seus processos de aplicação ou se funciona como referência para o desenvolvimento de raciocínio analógico'; e se a ratio decidendi deveria estar incluída no que se considera vinculante em um precedente são exemplos de controvertidas questões que podem afetar decisivamente a resposta da pergunta inicial ${ }^{2}$. Por isso, qualquer esforço conceitual voltado à identificação das propriedades definidoras de um precedente envolve um empreendimento intelectual exigente.

Consciente desses desafios, este trabalho possui objetivo mais modesto. Por meio de exemplos da prática decisória do Supremo Tribunal Federal (STF), busca-se apresentar características que podem sugerir, a partir do modo como o tribunal dialoga com o seu estoque de decisões na fundamentação de decisões atuais, uma definição muito ampla - e, talvez por isso, problemática - de precedente para a mais alta corte brasileira.

Esse pode ser um caminho promissor em pelo menos três sentidos. Em primeiro lugar, esse esforço, ao mesmo tempo analítico e ilustrativo, pode sugerir como hipótese para novas agendas de pesquisa - como parece ser o caso brasileiro - a existência de uma longa distância entre, de um lado, refinamento teórico e aprofundamento estrutural e, de outro, os resultados de uma prática de justificação desparametrizada. Em segundo lugar, os insumos da prática decisória da corte podem reforçar a importância tanto do enfrentamento de discussões teórico-conceituais relacionadas à definição e à propositura de métodos adequados de trabalho com precedentes como da busca por soluções institucionais destinadas a lidar com problemas de identificação, construção e aplicação dessas decisões no país. Finalmente, em terceiro lugar, os insumos da realidade decisória do tribunal podem ser úteis para aprendizado institucional em outras jurisdições que

V. SUNSTEIN, Cass R. Legal reasoning and political conflict. New York: Oxford University Press, 1996, p. 7172; e DUXBURY, Neil. The Nature and Authority of Precedent. Cambridge: CUP, 2008, p. 7. Como terceira possibilidade, há também quem conceba precedentes como concretizações e bases para a afirmação de algum princípio jurídico, que pode ser relevante para a solução de casos futuros. V. a respeito BANKOWSKI, Zenon et al. Rationales for precedent. In: MACCORMICK, D. Neil; SUMMERS, Robert S. (Org). Interpreting precedents: a comparative study. Aldershot: Ashgate/Dartmouth, 1997, p. 497. Como, porém, princípios podem informar o desenvolvimento de raciocínios analógicos e constituem a justificação subjacente de regras, opta-se neste trabalho por limitar os modelos básicos de trabalho com precedentes aos dois apresentados.

2 SCHAUER, Frederick. Thinking like a lawyer: a new introduction to legal reasoning. Cambridge: Harvard University Press, 2009, p. 36-60. 
vivenciam ou podem vivenciar problemas semelhantes. Se é verdadeiro que as fronteiras entre civil law e common law estão cada vez mais difusas ${ }^{3}$, conhecer diferentes propostas de organização institucional, de desenho do processo decisório para a construção de decisões e os desafios e disfuncionalidades que afetam o trabalho com precedentes em certa jurisdição se revela rica fonte para a busca de soluções para problemas que erroneamente podem ser considerados exclusivamente locais.

Diante, portanto, dessas três utilidades, este texto apresenta um inventário de possibilidades de, no geral, mau uso de decisões anteriores como se fossem precedentes para a justificação de decisões no STF. Nesse cenário, "o que é um precedente para o Supremo Tribunal Federal?" se apresenta, mais precisamente, como uma pergunta que pode ser respondida de pelo menos sete maneiras diferentes, todas elas, à luz de certos pressupostos normativos, problemáticas para que se possa afirmar possuir a mais alta corte brasileira uma prática saudável de precedentes ${ }^{4}$. Para o Supremo, um precedente pode se deixar apreender (i) pela ementa de um julgado, (ii) por passagens de decisões desvinculadas da questão central enfrentada no julgamento, (iii) por simples proximidade temática com o caso a ser decidido, (iv) por teses gerais apresentadas no processo de construção da ratio decidendi da decisão desvinculadas do caso decidido, (v) por uma decisão do pleno, de uma turma ou de um dos seus ministros, mesmo quando o que esteja em jogo seja a decisão de um caso atual pelo plenário, (vi) por decisões que não foram tomadas e (vii) pela possível utilidade de decisões passadas para o atingimento de finalidades que transcendem a solução do caso sob julgamento. É em torno dessas possibilidades que este trabalho se desenvolverá até a sua conclusão. Durante o desenvolvimento dos tópicos propostos, o trabalho adentrará em debates a respeito da definição, da fonte da força de vinculação de precedentes e de como variáveis institucionais podem afetar a construção e a aplicação de potenciais precedentes para a solução de casos específicos.

\section{A TRANSCRIÇÃO DE EMENTAS E A TRANSFERÊNCIA DOS ÔNUS DE PROVA E DE ARGUMENTAÇÃO PARA OS DESTINATÁRIOS DA DECISÃO}

Ementas são comumente utilizadas na prática forense para comunicar posições consolidadas em tribunais brasileiros. Elas estão, por isso, mais associadas à apresentação

\footnotetext{
3 MACCORMICK, D. Neil; SUMMERS, Robert S. (Org). Interpreting precedents: a comparative study. Aldershot: Ashgate/Dartmouth, 1997, p. 531 ss. BARBOZA, Estefânia Maria de Queiroz. Precedentes judiciais e segurança jurídica: fundamentos e possibilidades para a jurisdição constitucional brasileira. São Paulo: Saraiva, 2014, p. 76. Para uma crítica à possibilidade de sustentação da própria diferenciação v. PARGENDLER, Mariana. The rise and decline of legal families. The American Journal of Comparative Law, vol. 60, n. 4, p. 1043-1074, out. 2012. Disponível em: http://www.jstor.org/stable/41721695. Acesso em: 21 nov. 2019.

$4 \quad$ O desenvolvimento de uma prática saudável de precedentes pressupõe a superação dos ônus de justificação atrelados aos modos de trabalho com decisões passadas (aplicação, distinção e revogação) nos limites das concepções endossadas por decisores a respeito de suas relações com regras, exemplos ou princípios. Em qualquer caso, assume-se, ainda, que essa prática saudável também pressupõe o reconhecimento de força de vinculação aos precedentes decorrente do caráter autoritativo das razões que fornecem para a decisão.
} 
de jurisprudências, i.e. do produto da prática decisória reiterada de um órgão jurisdicional em um determinado sentido, do que precedentes. Independentemente desse fato, que passa por discussões conceituais sobre a distinção entre os dois, é possível dizer, como fazem Ferreira, Langenegger e Silva, que, no funcionamento rotineiro do direito, “[p]raticamente todas as petições, pareceres jurídicos, sentenças e votos contêm citações jurisprudenciais, em sua grande maioria em trechos de ementas, utilizadas como se fossem um resumo fiel do julgamento" ${ }^{5}$. Nesse quadro geral, é frequente encontrar decisões do Supremo Tribunal Federal, seguindo a tendência de juízos e tribunais no país, que fazem referência a precedentes da corte por meio da simples transcrição das ementas de julgados passados. Adriana Vojvodic, por exemplo, ao analisar a aplicação de precedentes na argumentação do STF, afirma que "o modo mais comum de se referir a precedentes é fazendo uso unicamente da numeração das decisões e, em segundo lugar, por meio da transcrição da ementa dos casos. Nas circunstâncias mais frequentes o que é usado é algum dos comandos presentes na ementa, ainda que ela como um todo não seja transcrita no texto do voto dos ministros" ${ }^{\prime \prime}$. Na ADPF 378/MC, por exemplo, em que se discutia a constitucionalidade do processo de impeachment da presidente Dilma Rousseff, o ministro Edson Fachin reproduziu em seu voto simplesmente a ementa da ADPF-QO 1 para afirmar, por meio de suposto precedente representativo da "jurisprudência firme" do STF, a competência da corte para "realizar o juízo acerca do que se há de compreender, no sistema constitucional brasileiro, como preceito fundamental"7.

É esperado, por um lado, que a ementa deva funcionar como um resumo dos debates e argumentos apresentados no julgamento que a gerou ${ }^{8}$. Quando isso ocorre, o seu emprego pode não ser problemático para a identificação e a aplicação do precedente que ela pretende sintetizar, especialmente quando, do seu texto, for fácil depreender o que foi decidido e por que a decisão anterior foi tomada9. Se se aceita, por exemplo,

\footnotetext{
5 FERREIRA, Carolina Cutrupi; LANGENEGGER, Natalia; SILVA, Marina Jacob Lopes da. Construção de ementas das decisões do Supremo Tribunal Federal. FGV Direito SP Research Paper Series, São Paulo, n. 125, jun. 2015, p. 4. Disponível em: https://papers.ssrn.com/sol3/papers.cfm?abstract_id=2623294. Acesso em: 05 abr. 2018.

6 VOJVODIC, Adriana. Precedentes e argumentação no Supremo Tribunal Federal: entre a vinculação ao passado e a sinalização para o futuro. 2012. Tese (Doutorado em Direito) - Faculdade de Direito, Universidade de São Paulo, São Paulo, 2012. Disponível em: https://www.teses.usp.br/teses/disponiveis/2/2134/tde-27092012094000/publico/tese_Adriana_Vojvodic.pdf. Acesso em: 28 fev. 2020, p. 181.

7 BRASIL. Supremo Tribunal Federal (plenário). Medida Cautelar Na Arguição De Descumprimento De Preceito Fundamental 378/ DF. ADPF 378 MC. Processo de Impeachment. Definição da legitimidade Constitucional do rito previsto na Lei № 1.079/1950. Adoção, como linha geral, das mesmas regras seguidas em 1992. Cabimento da ação e concessão parcial de medidas cautelares. Conversão em julgamento definitivo. Requerente: Partido Comunista do Brasil. Am. Curiae: Partido da Social Democracia Brasileira- PSDB e outros. Relator: Min. Edson Fachin. Relator do Acórdão: Min. Roberto Barroso, 17 de dezembro de 2015, p. 44. Disponível em: http:// redir.stf.jus.br/paginadorpub/paginador.jsp?docTP=TP\&docID=10444582. Acesso em: 05 nov. 2019.

8 FERREIRA, Carolina Cutrupi; LANGENEGGER, Natalia; SILVA, Marina Jacob Lopes da. Construção de ementas das decisões do Supremo Tribunal Federal. FGV Direito SP Research Paper Series, São Paulo, n. 125, jun. 2015, p. 4-5. Disponível em: https://papers.ssrn.com/sol3/papers.cfm?abstract_id=2623294. Acesso em: 05 abr. 2018.

9 SCHAUER, Frederick. Thinking like a lawyer: a new introduction to legal reasoning. Cambridge: Harvard University Press, 2009, p. 50.
} 
que um precedente guarda relações estruturais semelhantes às de uma regra ${ }^{10}$, a ementa pode cumprir um papel central para a identificação e a aplicação de um precedente quando ela explicita o padrão decisório que pode ser aplicado dedutivamente a fatos semelhantes para fins de solução do caso atual. Se se concebe, porém, um precedente como um exemplo ${ }^{11}$, a ementa pode ser útil ao identificar claramente as características centrais do caso fonte cuja presença no caso alvo são capazes de justificar a extração, para este, do mesmo resultado do julgado anterior. Nesses casos, assim como a menção apenas ao dispositivo de decisões passadas, o apelo frequente a ementas contribuiria para a manutenção de coerência, no tempo, entre decisões e, com isso, a percepção de que o decisor não descarta ou instrumentaliza o passado ${ }^{12}$.

Apesar dessa possibilidade de justificar o apelo genérico a ementas para a localização de precedentes, há, contudo, fortes razões para desconfiar da real utilidade dessa prática em si para o trabalho adequado com precedentes no STF. Essas razões estão basicamente relacionadas ao processo de construção das ementas no tribunal. Diante da ausência de qualquer padrão para a sua elaboração ${ }^{13}$, é possível identificar traços problemáticos naqueles que deveriam funcionar como resumos organizados e claros das decisões da corte. No fundo, dado que os gabinetes dos ministros adotam os seus próprios critérios para a redação das ementas, o produto desse trabalho precisa ser utilizado com cuidado.

Como revela pesquisa feita por Ferreira, Langenegger e Silva em 54 julgados da corte $^{14}$, as ementas podem (i) tanto não guardar nenhuma relação com o acórdão (ii) como passar exaustivamente por todas as questões discutidas nos demais votos do julgado. Além disso, as ementas podem (iii) até evidenciar as conclusões a que chegam os ministros, mas não apresentar os seus fundamentos ${ }^{15}$. Em complemento a esses diagnósticos, é possível, ainda, encontrar ementas com informações (iv) em excesso ${ }^{16}$ e ementas

\footnotetext{
10 Sobre semelhanças estruturais entre regras e precedentes. V. SCHAUER, Frederick. Thinking like a lawyer: a new introduction to legal reasoning, Cambridge: Harvard University Press, 2009, p. 50.

11 LEVENBOOK, Barbara. The meaning of a precedent. Legal Theory, vol. 6, n. 2, jun. 2000, p. 185-240.

12 VOJVODIC, Adriana. Precedentes e argumentação no Supremo Tribunal Federal: entre a vinculação ao passado e a sinalização para o futuro. 2012. Tese (Doutorado em Direito) - Faculdade de Direito, Universidade de São Paulo, São Paulo, 2012. Disponível em: https://www.teses.usp.br/teses/disponiveis/2/2134/tde-27092012094000/publico/tese_Adriana_Vojvodic.pdf. Acesso em: 28 fev. 2020, p. 174. Para a autora, o recurso a precedentes "com base unicamente no dispositivo decisório parece ser regra nos votos dos ministros".

13 FERREIRA, Carolina Cutrupi; LANGENEGGER, Natalia; SILVA, Marina Jacob Lopes da. Construção de ementas das decisões do Supremo Tribunal Federal, FGV Direito SP Research Paper Series, São Paulo, n. 125, jun. 2015, p. 7-8. Disponível em: https://papers.ssrn.com/sol3/papers.cfm?abstract_id=2623294. Acesso em: 05 abr. 2018.

14 FERREIRA, Carolina Cutrupi; LANGENEGGER, Natalia; SILVA, Marina Jacob Lopes da. Construção de ementas das decisões do Supremo Tribunal Federal, FGV Direito SP Research Paper Series, São Paulo, n. 125, jun. 2015, p. 9 ss. Disponível em: https://papers.ssrn.com/sol3/papers.cfm?abstract_id=2623294. Acesso em: 05 abr. 2018.

15 Idem, p. 10.

16 V. MS 31.697/DF, em que a menção ao princípio constitucional da moralidade aparece apenas na ementa. BRASIL. Supremo Tribunal Federal (1. Turma). Mandado De Segurança 31.697/ DF. Ato do Conselho Nacional do Ministério Público. Competência reconhecida para fiscalizar os princípios que regem a administração pública, consagrados no art. 37, caput, da Constituição Federal. Cessão de servidor público. Ausência dos pressupostos legais objetivos. Prevalência de interesse público sobre o privado. Impropriedade do debate. Impossibilidade de dilação probatória. Segurança indeferida Impetrante: Gustavo Henrique Cantenhe de Morgado e Outros.
} 
(v) que não incorporam posições concorrentes ou dissidentes relativamente à do ministro designado para redigi-la, restringindo-se ao voto do relator para o acórdão ${ }^{17}$.

Esses achados evidenciam, como causa, um problema do processo decisório do Supremo e criam uma consequência negativa para a aplicação de decisões passadas como precedentes para a solução de casos futuros. No primeiro aspecto, a baixa colegialidade entre os ministros ${ }^{18}$ aliada à adoção de um modelo seriatim (ou por agregação de manifestações individuais ${ }^{19}$ ) para a formação da vontade da corte criam as condições para que os acórdãos, "[e]m vez de manifestarem um caráter binário de perda ou ganho", tornem-se "uma coleção de argumentos favoráveis e contrários. [Nesse cenário,] para determinar quem perde ou ganha o caso, e, mais importante, qual a regra do caso e o quão forte é o precedente utilizado, é necessário contar'por cabeça"'20. Transpostas essas características do processo decisório para a confecção das ementas, a dificuldade de se captar em certos casos o que, de fato, foi decidido e com base em quais argumentos a decisão foi tomada acaba funcionando, na prática, como desincentivo para que o responsável pela redação dos resumos dos julgados expresse neles toda a complexidade dos votos dos demais integrantes da corte e dos debates por eles eventualmente gerados. Por isso, como consequência perversa, a mera transcrição de uma ementa se limita, no máximo ${ }^{21}$, a simplesmente transferir para os destinatários da decisão os ônus (i) de identificação dos fatos e fundamentos jurídicos relevantes do caso precedente, (ii) de aproximação do caso precedente ao caso atual e (iii) de aplicação neste da resposta atribuída àquele. Como se nota, aspectos do desenho institucional também interferem na qualidade da

Impetrado: Presidente do Conselho Nacional do Ministério Público - CNMP. Relator: Min. Dias Toffoli, 11 de março de 2014. Disponível em: http://redir.stf.jus.br/paginadorpub/paginador.jsp?docTP=TP\&docID=5568219. Acesso em: 05 nov. 2019.

17 V. reportagem no site Consultor Jurídico sobre as reações dos ministros após a publicação da ementa da ADPF 130, em que se discutiu a recepção pela nova ordem constitucional da chamada "lei de imprensa", publicada durante o regime anterior. Na notícia, lê-se que: "alguns ministros entenderam que Carlos Ayres Britto foi além do que teria sido julgado na derrubada da lei de imprensa. (...) A ementa é um libelo a favor da liberdade de expressão e de imprensa. Ayres Britto escreveu, por exemplo, que deve ser "respeitada sempre a ideia-força de que quem quer que seja tem o direito de dizer o que quer que seja". Em seguida: "Logo, não cabe ao Estado, por qualquer dos seus órgãos, definir previamente o que pode ou o que não pode ser dito por indivíduos e jornalistas". (...) Publicada a ementa no dia 6.nov.2009, alguns magistrados começaram a torcer o nariz em privado. Em vez de encarar o problema publicamente, questionar o que foi publicado (a redação do ministro Carlos Ayres Britto), esse grupo de magistrados passou resmungar pelos cantos, aspergindo maledicências uns contra os outros". CENSURA a jornal se deve a discórdia entre ministros. Revista Consultor Jurídico, 16 dez. 2009. Disponível em: https://www.conjur.com.br/2009-dez-16/ censura-estadao-discordia-lei-imprensa. Acesso em: 12 nov. 2019.

18 SILVA, Virgílio Afonso da. Deciding without deliberating. International Journal of Constitutional Law, vol. 11, n. 3, p. 557-584, 2013. Disponível em: https://doi.org/10.1093/icon/mot019. Acesso em: 21 nov. 2019.

19 V. HENDERSON, M. Todd. From seriatim to consensus and back again: A theory of dissent. The Supreme Court Review, vol. 2007, n. 1, p. 283-344, 2007. Disponível em: https://doi.org/10.1086/655172. Acesso em: 22 nov. 2019.

20 HENDERSON, M. Todd. From seriatim to consensus and back again: A theory of dissent. The Supreme Court Review, vol. 2007, n. 1, 2007, p. 298-299. Disponível em: https://doi.org/10.1086/655172. Acesso em: 22 nov. 2019. Tradução Livre.

21 Esse melhor papel desempenhado pela mera referência a uma ementa como precedente ocorre quando existe, de fato, relação entre o caso atual e o caso precedente, e não mera referência aleatória ou mesmo estratégica de uma decisão passada que se pretende aplicar como se precedente fosse para a solução de um caso atual. 
justificação e podem contribuir para explicar problemas no trabalho com precedentes no Supremo.

Diante desse quadro, a evocação de uma ementa, apesar da frequência com que ocorre, torna-se quase sempre insuficiente para a identificação e a aplicação de precedentes. Há, na verdade, um uso argumentativamente limitado do julgado passado para a justificação da decisão atual22, que só se torna útil quando as semelhanças entre os casos são evidentes e a reiteração de um posicionamento preexistente se revela suficiente para a justificação. Nesses casos, ainda que a justificação possa ser, à luz de um referencial normativo, insuficiente, a clareza da aplicabilidade do precedente tornaria essa limitação menos danosa para se aferir a adequação da menção ao passado para orientar o julgamento do caso atual. Independentemente, no entanto, do acerto decorrente da citação ao precedente aplicável, seja ela meramente nominal ou pelo recurso à ementa ou parte dela, persiste um problema na qualidade da justificação da decisão.

\section{O APELO A OBITER DICTA}

O emprego de obiter dicta abusivos no Supremo é um problema já mapeado ${ }^{23}$. De maneira simples, a expressão "obiter dictum" poderia ser traduzida como "algo dito de passagem" ${ }^{24}$. As dicta expressam manifestações não vinculantes da decisão tomada, uma vez que não guardam relação direta nem com o resultado do julgado nem com a sua fundamentação. Por essa razão, elas não poderiam ser evocadas no futuro como mecanismos de constrangimento das decisões da própria corte que as pronunciou (numa hipótese típica de vinculação horizontal) ou de tribunais inferiores a ela vinculados (caso de vinculação vertical), ainda que a realidade evidencie o contrário ${ }^{25}$.

Sem embargo dessa visão tradicional, é possível, pragmaticamente, atribuir aos dicta papéis importantes no processo decisório de uma corte suprema, como o STF. Como indica Bustamante, eles podem ser usados "para alertar à comunidade jurídica uma possível modificação futura que se pretende fazer no direito judicial, ou para requerer ao legislador que mude uma determinada lei, ou para realizar uma promessa em relação a uma decisão futura, caso determinada matéria venha a ser apreciada pela corte em um caso posterior, ou para interpretar proposições jurídicas mais abstratas, que apenas indiretamente se relacionam com o caso em juízo; ou ainda, em exemplos menos honrados,

\footnotetext{
22 VOJVODIC, Adriana. Precedentes e argumentação no Supremo Tribunal Federal: entre a vinculação ao passado e a sinalização para o futuro. 2012. Tese (Doutorado em Direito) - Faculdade de Direito, Universidade de São Paulo, São Paulo, 2012. Disponível em: https://www.teses.usp.br/teses/disponiveis/2/2134/tde-27092012094000/publico/tese_Adriana_Vojvodic.pdf. Acesso em: 28 fev. 2020, p. 182.

23 BUSTAMANTE, Thomas da Rosa de. Obiter dicta abusivos: esboço de uma tipologia dos pronunciamentos judiciais ilegítimos. Revista Direito GV, São Paulo, vol. 14, n. 2, p.707-745, mai./ago. 2018. Disponível em: http:// dx.doi.org/10.1590/2317-6172201827. Acesso em: 12 jul. 2019.

24 SCHAUER, Frederick. Thinking like a lawyer: a new introduction to legal reasoning, Cambridge: Harvard University Press, 2009, p. 55-56.

25 V. no plano internacional MARSHALL, Geoffrey. What is binding in a precedent. In: MACCORMICK, D. Neil; SUMMERS, Robert S. (Org). Interpreting precedents: a comparative study. Aldershot: Ashgate/Dartmouth, 1997, p. 515.
} 
para oferecer apoio a um determinado grupo político particular, ou constranger uma determinada autoridade a decidir um caso ou matéria que ainda não está sob a jurisdição da corte que prolatou o obiter dictum ${ }^{26}$. O último exemplo, para o autor, evidenciaria o seu uso abusivo. Para além desses casos, porém, seria também possível afirmar que eles poderiam ser usados como se compusessem partes de precedentes. E a prática decisória do Supremo Tribunal Federal parece dar pistas de que essa forma de emprego de dicta não é desconhecida na corte.

Um exemplo pode ser esclarecedor. No julgamento dos embargos infringentes da ação penal 470 - conhecida como "caso Mensalão" -, o ministro Luís Roberto Barroso, ao defender que o artigo 333 do Regimento Interno da corte não havia sido revogado pela lei 8.038/90, evocou em certo momento "inúmeros precedentes" para justificar a sua posição ${ }^{27}$. Para Barroso, decisões anteriores de ministros do Supremo reconheciam a validade do dispositivo do regimento que previa o cabimento dos embargos na hipótese sob discussão, em que houve condenação de réus em ação penal julgada procedente na corte por maioria, mas com, pelo menos, quatro votos dissidentes ${ }^{28}$.

Durante a leitura dos alegados precedentes, o ministro Barroso foi questionado pelos ministros Joaquim Barbosa e Marco Aurélio sobre o real caráter de "precedentes" dessas manifestações. Em meio a uma série de razões para descaracterizar a força de vinculação dos trechos citados pelo ministro, Joaquim Barbosa e Marco Aurélio questionaram se as passagens citadas "constavam da ementa [dos julgados]", "se estavam na fundamentação", se eles estavam em "acórdãos da lavra do plenário" ou se, no fundo, não passavam de "frases esparsas" lançadas no meio de votos, mas que não guardavam nenhuma relação com o que estava sendo discutido nos casos anteriores ${ }^{29}$. Decisiva para a presente discussão é a fala do ministro Barroso que reconhece haver um possível problema na suposta estratégia de vincular o plenário do tribunal aos seus próprios precedentes. Ao ser questionado por Joaquim Barbosa se os trechos citados não seriam "meros obiter dicta", diz Barroso em determinado momento: "[e]u refleti sobre essa questão, Presidente, e, verdadeiramente, as referências, no mais das vezes, foram feitas, sim, em

\footnotetext{
26 BUSTAMANTE, Thomas da Rosa de. Obiter dicta abusivos: esboço de uma tipologia dos pronunciamentos judiciais ilegítimos, op. cit., p. 719.

27 V. PLENO - STF inicia julgamento de cabimento de embargos infringentes na AP 470 (1/2). [S.I.: s.n.], 2013.1 Vídeo (1hr59min38s). Publicado pelo canal STF. Disponível em: https://youtu.be/TWy9wd18mfM. Acesso em: 12 nov. 2019. A partir do minuto 31:25.

28 Confira-se o dispositivo: “Art. 333. Cabem embargos infringentes à decisão não unânime do Plenário ou da Turma: I - que julgar procedente a ação penal; II - que julgar improcedente a revisão criminal; III - que julgar a ação rescisória; IV - que julgar a representação de inconstitucionalidade; $V$ - que, em recurso criminal ordinário, for desfavorável ao acusado. Parágrafo único. O cabimento dos embargos, em decisão do Plenário, depende da existência, no mínimo, de quatro votos divergentes, salvo nos casos de julgamento criminal em sessão secreta" (SUPREMO TRIBUNAL FEDERAL. Emenda Regimental n 2, de 4 de dezembro de 1985. Altera os artigos 21, 67, $134,169,174,181,226,228,234,235,236,239,277,325,326,327,328,329,333,355,356$, e 357 do Regimento Interno. Diário da Justiça: seção 1, Brasília, DF, p. 22717, 09 dez. 1985).

29 PLENO - STF inicia julgamento de cabimento de embargos infringentes na AP 470 (1/2). [S.I.: s.n.], 2013.1 Vídeo (1hr59min38s). Publicado pelo canal STF. Disponível em: https://youtu.be/TWy9wd18mfM. Acesso em: 12 nov. 2019.
} 
obiter dicta ou na motivação da decisão. Mas claramente na construção do seu argumento, todos esses ministros consideraram que o artigo 333 estava em vigor" ${ }^{\prime 30}$.

O exemplo revela, na justificação criada pelo próprio ministro, a tentativa de articular argumentos em torno de precedentes a partir da costura de passagens de decisões anteriores que expressam tanto partes da ratio decidendi como trechos de obiter dicta. No entanto, se é correto que dicta não guardam nenhum caráter autoritativo - e, portanto, não vinculante -, existe um possível erro conceitual ao vinculá-las com autênticos precedentes da corte. Em reforço da tese de Bustamante, tal conclusão não precisa ser ampliada a ponto de sustentar a irrelevância absoluta do obiter dictum. Ele pode desempenhar papel persuasivo para a sustentação de argumentos, especialmente quando se relaciona, de alguma forma, com o desfecho do caso julgado. Se a hipótese mais clara de dictum é a manifestação judicial irrelevante para o enfrentamento do caso ou de qualquer questão jurídica importante para o desfecho do problema, é possível também encontrar situações em que a separação entre opiniões aparentemente laterais e a solução do próprio caso não é evidente. Para dizer com Cardozo, obiter dicta "não são sempre etiquetados como tais e não são sempre reconhecíveis com um piscar de olhos" ${ }^{\prime \prime 1}$. Essa sobreposição pode ocorrer quando o trecho de uma manifestação judicial é relevante (i) para a composição do caso, mas não necessária para sustentar a regra de decisão, (ii) para lidar com alguma controvérsia acessória do caso atual ou (iii) para o enfrentamento de outras questões importantes que podem surgir em outros casos ${ }^{32}$. Desvinculados do caso decidido e de seus fundamentos, porém, ainda que se possa discutir a existência de "precedentes persuasivos"33, i.e. de decisões passadas cuja força de vinculação se extrai das razões substantivas que fornece para a solução de casos atuais, e não de razões autoritativas, segue sendo difícil relacionar conceitualmente dicta com precedentes.

O debate coloca sobre a mesa um problema teórico que interfere diretamente na resposta da pergunta "o que é um precedente para o Supremo?". O apelo a dicta, ementas e a outras partes de decisões parece indicar que o tribunal encara seu estoque de julgados como fontes de razões persuasivas para a justificação de casos atuais. Sendo correto o diagnóstico, isso significa que a corte tende a tratar, em diversos casos, como substantiva a natureza da obrigação de observar suas próprias manifestações anteriores, o que torna os seus precedentes fontes mais fracas de razões para decidir. Nessa visão, a corte usa as suas decisões passadas para se convencer da adequação da resposta constitucional que desenvolve para o caso atual. Julgados passados ou partes deles são, no fundo, peças articuladas a cada novo caso para a fundamentação da solução jurídica

\footnotetext{
30 PLENO - STF inicia julgamento de cabimento de embargos infringentes na AP 470 (1/2). [S.I.: s.n.], 2013.1 Vídeo (1hr59min38s). Publicado pelo canal STF. Disponível em: https://youtu.be/TWy9wd18mfM. Acesso em: 12 nov. 2019. A partir do minuto 31:47.

31 CARDOZO, Benjamin N. The Nature of the Judicial Process. New Haven: Yale University Press, 1921, p. 30 apud DUXBURY, Neil. The Nature and Authority of Precedent. Cambridge: CUP, 2008, p. 69.

32 MARSHALL, Geoffrey. What is binding in a precedent. In: MACCORMICK, D. Neil; SUMMERS, Robert S. (Org). Interpreting precedents: a comparative study. Aldershot: Ashgate/Dartmouth, 1997, p. 515.

33 LEGALE, Siddharta. Superprecedentes. Revista Direito GV, São Paulo, vol. 12, n. 3, p. 810-845, set./dez. 2016. Disponível em: http://dx.doi.org/10.1590/ 2317-6172201633. Acesso em: 21 nov. 2019.
} 
mais adequada para o problema levado à corte. Nesse papel, eles não vinculam pelo seu status de manifestação institucional anterior, mas apenas fornecem argumentos que podem, ou não, ser usados para a construção da decisão presente. Com isso, o passado é referência para o aprendizado institucional, e não, com base no seu status autoritativo, para a sustentação de deveres de coerência.

Por trás dessa constatação está uma central disputa conceitual: afinal, um precedente persuasivo pode ser um precedente? As respostas afirmativas parecem comumente se fundamentar mais sobre descrições de como alegados precedentes funcionam na prática $^{34}$ do que em construções teórico-conceituais preocupadas com a identificação das propriedades definidoras de um precedente. De fato, cortes em diversas jurisdições recorrem às suas próprias decisões e a decisões de outros tribunais aos quais não estão formalmente vinculados para o desenvolvimento das suas próprias cadeias de argumentação ou para simplesmente mostrar que o resultado que sugerem em um caso específico se harmoniza com outros julgados ${ }^{35}$. Ainda que não se reconheça força de vinculação em decisões anteriores ou que tribunais atuem como se essa força não existisse, julgados chamados de precedentes são considerados referenciais influentes quando em torno deles se constroem diálogos entre o passado e o presente no enfrentamento de problemas específicos. E isso ocorre "seja para aplicar essas decisões passadas [em um caso atual], seja para explicitar o porquê de sua não aplicação"36.

Por isso, precedentes persuasivos são uma realidade na prática decisória de provavelmente qualquer juízo ou tribunal, especialmente de tribunais de cúpula. A sua existência revela como respeitar precedentes na prática decisória de um tribunal pode estar desvinculado de caracterizá-los como vinculantes ${ }^{37}$. Reconhecê-lo, contudo, não é necessariamente suficiente para se chegar a uma caracterização compreensiva do que

34 V. MELLO, Patrícia Perrone Campos; BARROSO, Luís Roberto. Trabalhando com uma nova lógica: a ascensão dos precedentes no direito brasileiro. Revista da AGU, vol. 15, n. 3, jul./set. 2016, p. 19. Disponível em: https:// doi.org/10.25109/2525-328X.v.15.n.03.2016.854. Acesso em: 20 nov. 2019. Para os autores "[h]á, primeiramente, os precedentes com eficácia meramente persuasiva. Esta é a eficácia que tradicionalmente se atribuía às decisões judiciais em nosso ordenamento, em razão de sua própria raiz romano-germânica. Os julgados com esta eficácia produzem efeitos restritos às partes e aos feitos em que são afirmados, são relevantes para a interpretação do direito, para a argumentação e para o convencimento dos magistrados; podem inspirar o legislador; e sua reiteração dá ensejo à produção da jurisprudência consolidada dos tribunais. São, contudo, fonte mediata ou secundária do direito".

35 SUMERS, Robert. S. Precedent in the United States (New York State). In: MACCORMICK, D. Neil; SUMMERS, Robert S. (Org). Interpreting precedents: a comparative study. Aldershot: Ashgate/Dartmouth, 1997, p. 368. O autor organiza a força de vinculação de precedentes em 4 grandes categorias: a vinculação formal; decisões não formalmente vinculantes, mas que exercem pressão sobre casos futuros; precedentes não formalmente vinculantes e sem força; decisões que desempenham papeis meramente ilustrativos ou tenham outro valor. V. também LEGALE, Siddharta. Superprecedentes, Revista Direito GV, São Paulo, vol. 12, n. 3, set./dez. 2016 , p. 823. Disponível em: http://dx.doi.org/10.1590/ 2317-6172201633. Acesso em: 21 nov. 2019.

36 VOJVODIC, Adriana. Precedentes e argumentação no Supremo Tribunal Federal: entre a vinculação ao passado e a sinalização para o futuro. 2012. Tese (Doutorado em Direito) - Faculdade de Direito, Universidade de São Paulo, São Paulo, 2012. Disponível em: https://www.teses.usp.br/teses/disponiveis/2/2134/tde-27092012094000/publico/tese_Adriana_Vojvodic.pdf. Acesso em: 28 fev. 2020, p. 85.

37 VOJVODIC, Adriana. Precedentes e argumentação no Supremo Tribunal Federal: entre a vinculação ao passado e a sinalização para o futuro. 2012. Tese (Doutorado em Direito) - Faculdade de Direito, Universidade de São Paulo, São Paulo, 2012. Disponível em: https://www.teses.usp.br/teses/disponiveis/2/2134/tde-27092012094000/publico/tese_Adriana_Vojvodic.pdf. Acesso em: 28 fev. 2020, p. 86. 
define um precedente e de onde provém a sua força de vinculação. Mesmo defensores de precedentes persuasivos reconhecem "que a inexistência de efeitos vinculantes tornaria o caso um mero exemplo, e não um precedente no sentido próprio do termo"38. O ponto, portanto, é saber se uma caracterização mais precisa da ideia de precedente pressupõe, ou não, alguma força de vinculação decorrente do seu próprio status de manifestação institucional.

Para Schauer, a ideia básica por trás de uma "lógica" de trabalho com precedentes seria: o passado deve ser observado apenas pelo fato de ser passado, na medida em que a manifestação de uma autoridade decisória é, em um Estado de Direito, encarada como fonte para o estabelecimento de expectativas legítimas sobre o seu comportamento esperado no futuro. Isso porque precedentes, por trás da decisão que enunciam para um caso específico, comunicariam para os seus destinatários atuais e potenciais promessas feitas pelo decisor de manutenção do mesmo resultado para futuros problemas semeIhantes. E isso sem considerações específicas sobre o conteúdo do próprio julgado. Em conclusão que deve soar contraintuitiva para participantes de práticas propriamente jurídicas (especialmente juízes), afirma o autor que, se um tribunal "estiver genuinamente convencido do mérito daquele raciocínio [o raciocínio de outro tribunal], não estará de forma alguma se pautando por - obedecendo - precedentes"39. Aprender com o passado ou ser persuadido por ele não é o mesmo que atribuir a ele o status de precedente. Definir uma decisão passada como precedente, ao contrário, pressupõe observância não porque se concorda com ela, mas, na verdade, inclusive quando se acha que ela foi um erro ${ }^{40}$. "É a fonte ou status do precedente que lhe dá a sua força, e não a solidez do seu raciocínio, nem a convicção, por parte do tribunal atual, de que o resultado indicado pelo precedente estava certo"41. Precedente, portanto, é uma decisão que, por si só, exerce algum tipo de pressão do passado sobre processos decisórios presentes pelo fato de derivar de uma manifestação de uma autoridade oficial do direito. A força de vinculação de um precedente, decorre, assim, do reconhecimento de que ele produz razões autoritativas para os seus destinatários, o que quer dizer que ele fornece razões para agir independentes de considerações sobre o próprio conteúdo da prescrição que recomenda e que exigem a superação de ônus especiais de argumentação para a sua superabilidade.

Essa não é certamente a única maneira de explicar como precedentes vinculam decisores. A relação entre precedentes e razões autoritativas como as apresentadas aproxima o trabalho com decisões passadas do trabalho com regras - essa, aliás, é a visão de

\footnotetext{
38 LEGALE, Siddharta. Superprecedentes, Revista Direito GV, São Paulo, vol. 12, n. 3, set./dez. 2016, p. 823. Disponível em: http://dx.doi.org/10.1590/ 2317-6172201633. Acesso em: 21 nov. 2019.

39 SCHAUER, Frederick. Thinking like a lawyer: a new introduction to legal reasoning, Cambridge: Harvard University Press, 2009, p. 38.

40 SCHAUER, Frederick. Thinking like a lawyer: a new introduction to legal reasoning, Cambridge: Harvard University Press, 2009, p. 41.

${ }^{41}$ SCHAUER, Frederick. Thinking like a lawyer: a new introduction to legal reasoning, Cambridge: Harvard University Press, 2009, p. 41.
} 
Schauer ${ }^{42}$ - e, assim, torna-o menos passível de alteração e adaptação ${ }^{43}$. Mas, como já dito, precedentes podem vincular também pelos exemplos que sugerem para a solução de casos futuros ${ }^{44}$ ou pelos princípios que estabelecem ${ }^{4546}$.

Em qualquer das diferentes concepções, contudo, isso não significa que precedentes exigem sempre a sua observância. Para além das possibilidades de interpretação e construção frequente dos sentidos de precedentes que as concepções que os aproximam de casos exemplares e expressões de princípios possibilitam, é possível, mesmo na concepção de precedentes como padrões de justificação próximos a regras, distinguir casos - e, assim, resolvê-los substantivamente como se estivessem sendo julgados pela primeira vez - ou mesmo superar precedentes que se mostrem inadequados para o órgão jurisdicional que os estabeleceu ${ }^{47}$. Vincular precedentes a razões autorizativas não significa que eles não sejam derrotáveis, mas que a constatação da sua incidência os torna mais resistentes a argumentos substantivos que pretendem afastá-los. Assim, em qualquer contexto, relacionar à definição de precedentes um caráter autoritativo significa torná-los um referencial de justificação que não se encontra simplesmente à disposição do tomador de decisão. Eles não podem ser lembrados ou esquecidos segundo a conveniência ou o grau de concordância, por parte do decisor, com o que eles estabelecem como resposta jurídica adequada para determinado problema. Mesmo quem pretenda não utilizar o precedente aplicável precisa considerá-lo e com ele dialogar ${ }^{48}$. $\mathrm{E}$ é desse simples fato que se extrai, da maneira mais básica, a pressão que julgados passados deveriam necessariamente exercer sobre processos decisórios atuais que enfrentam casos em alguma medida semelhantes a outros já enfrentados pelo mesmo tribunal ou por outro que se possa considerar - institucional e/ou legalmente ${ }^{49}$ - por ele vinculado ${ }^{50}$.

42 SCHAUER, Frederick. Thinking like a lawyer: a new introduction to legal reasoning, Cambridge: Harvard University Press, 2009, p. 62.

43 DUXBURY, Neil. DUXBURY, Neil. The Nature and Authority of Precedent. Cambridge: CUP, 2008, p. 108. V. também VOJVODIC, Adriana. Precedentes e argumentação no Supremo Tribunal Federal: entre a vinculação ao passado e a sinalização para o futuro. 2012. Tese (Doutorado em Direito) - Faculdade de Direito, Universidade de São Paulo, São Paulo, 2012. Disponível em: https://www.teses.usp.br/teses/disponiveis/2/2134/tde27092012-094000/publico/tese_Adriana_Vojvodic.pdf. Acesso em: 28 fev. 2020, p. 231.

44 LEVENBOOK, Barbara. The meaning of a precedent. Legal Theory, vol. 6, n. 2, jun. 2000, p. 188 ss.

45 DUXBURY, Neil. The Nature and Authority of Precedent. Cambridge: CUP, 2008, p. 62.

46 V. sobre o assunto MAUÉS, Antônio M.. Jogando com os precedentes: regras, analogias, princípios. Revista Direito GV, vol. 16, n. 2, 2012, p. 587-623.

47 Para Daniel Mitidiero, "distinguishing e overruling são técnicas que justamente pressupõem a força vinculante do precedente" (ênfases no original). V. MITIDIERO, Daniel. Precedentes: da persuasão à vinculação. $3^{a}$. ed. São Paulo: Revista dos Tribunais, 2018, p. 95.

48 DUXBURY, Neil. The Nature and Authority of Precedent. Cambridge: CUP, 2008, p. 127.

49 V., por exemplo, o artigo 927 do CPC, consoante o qual "os juízes e os tribunais observarão (...) a orientação do plenário ou do órgão especial aos quais estiverem vinculados" (BRASIL. Lei n 13.105, de 16 de março de 2015. Código de Processo Civil. Brasília, DF: Presidência da República, 16 mar. 2015. Disponível em: http://www. planalto.gov.br/ccivil_03/_ato2015-2018/2015/lei/l13105.htm. Acesso em: 22 nov. 2019).

50 Antes que se afirme que esse caráter autoritativo decorre apenas da aproximação de precedentes com regras, ele também é defendido por concepções que caracterizam precedentes como exemplos. Para Levenbook, por exemplo, "exemplar force is independent of background justifications". V. LEVENBOOK, Barbara. The meaning of a precedent. Legal Theory, vol. 6, n. 2, jun. 2000, p. 192. 
Por conseguinte, enquanto a expressão "precedente autoritativo" seria uma redundância, o rótulo "precedente persuasivo" seria uma contradição. Como afirma Wasserstrom "se decisões anteriores podem guiar o comportamento em um sistema jurídico se e somente se essas decisões anteriores forem 'corretas', então se torna relevante perguntar 'de que forma faz sentido falar em seguir um precedente?'. Isso porque, se a doutrina de precedentes possui algum significado expressivo, este indicaria que precedentes podem ser seguidos porque são precedentes, e não porque são resultados 'corretos'.'51.

Se essa caracterização pode soar à primeira vista estranha, ela passa a fazer mais sentido quando (i) o próprio direito positivo estabelece o cabimento de recursos que podem ser baseados apenas na inobservância de decisões anteriores (i.e. independentemente de argumentos materiais sobre a correção do que foi decidido) ${ }^{52}$ e (ii) se espera a superação de ônus especiais de argumentação nos casos de revogação de precedentes, como estabelece o Código de Processo Civil no parágrafo quarto do artigo $927^{53}$. O ônus qualificado, neste último caso, só se faz justificado quando são vinculadas ao precedente razões para a sua observância que, mais uma vez, não estão relacionadas à sua correção. Fosse o contrário, não seria necessário que o tribunal "dialogasse com a sua história" de maneira profunda ${ }^{54}$, mas simplesmente que mostrasse por que a decisão anterior poderia ser considerada errada e por que a decisão que se propõe em substituição a ela é substantivamente melhor. E se esse raciocínio faz sentido, então a ideia de precedentes persuasivos soa conceitualmente problemática, ainda que a construção de uma teoria compreensiva sobre precedentes no país precise acomodar - explicando, justificando ou mesmo criticando - o uso doutrinário ou sugestivo de julgados anteriores pelo Supremo e pelas instâncias a ele vinculadas.

É claro que a impossibilidade de defesa de "precedentes persuasivos" traz diversas implicações para a definição e aplicação de precedentes. Mas, em muitos casos, aquilo que pode ser considerado inadequado no trabalho com precedentes autoritativos também vale para o manejo de decisões sugestivas. $\mathrm{O}$ apelo à ementa e o emprego de obter dicta no Supremo Tribunal Federal são dois problemas já enfrentados compartilhados

51 WASSERSTROM, Richard. The Judicial Decision. Stanford: Stanford University Press, 1961, p. 52, apud LEVENBOOK, Barbara. The meaning of a precedent. Legal Theory, vol. 6, n. 2, jun. 2000, p. 191 (tradução livre).

52 No caso do Supremo, a reclamação seria o remédio por excelência para preservar a autoridade das decisões da corte. V. MELLO, Patrícia Perrone Campos; BARROSO, Luís Roberto. Trabalhando com uma nova lógica: a ascensão dos precedentes no direito brasileiro. Revista da AGU, vol. 15, n. 3, jul./set. 2016, p. 19-20. Disponível em: https://doi.org/10.25109/2525-328X.v.15.n.03.2016.854. Acesso em: 20 nov. 2019. No artigo os autores defendem que o cabimento de reclamação é que caracteriza decisões do Supremo como "precedentes normativos em sentido forte". Para as decisões para as quais "a lei não permite o uso de reclamação, em caso de desrespeito à orientação neles traçada", resta, na tipologia dos autores, o papel de precedentes com eficácia intermediária.

53 Segundo o dispositivo "[a] modificação de enunciado de súmula, de jurisprudência pacificada ou de tese adotada em julgamento de casos repetitivos observará a necessidade de fundamentação adequada e específica, considerando os princípios da segurança jurídica, da proteção da confiança e da isonomia" (BRASIL. Lei n 13.105, de 16 de março de 2015. Código de Processo Civil. Brasília, DF: Presidência da República, 16 mar. 2015. Disponível em: http://www.planalto.gov.br/ccivil_03/_ato2015-2018/2015/lei/l13105.htm. Acesso em: 22 nov. 2019).

54 VOJVODIC, Adriana de Moraes; MACHADO, Ana Mara França; CARDOSO, Evorah Lusci Costa. Escrevendo um romance, primeiro capítulo: precedentes e processo decisório no STF. Revista Direito GV, São Paulo, vol. 5, n. 1, jan./jun. 2009, p. 36. Disponível em: http://www.scielo.br/pdf/rdgv/v5n1/a02v5n1. Acesso em: 21 nov. 2019. 
pelos dois tipos de precedentes. Como se verá, porém, eles não são os únicos. E, quanto mais problemas relacionados à identificação do que a corte considera como precedente puderem ser mapeados, mais tenderá a ficar claro que, para além das aludidas discussões conceituais envolvendo autoridade e substância, praticamente qualquer coisa, do ponto de vista da própria prática decisória da corte, tem o potencial para representar um precedente do Supremo.

\section{A APROXIMAÇÃO MERAMENTE TEMÁTICA}

A evocação de supostos precedentes para a solução de problemas jurídicos no Supremo pode se dar a partir de relações muito gerais entre a questão fática já decidida e a que exige uma decisão no presente. Essas relações chegam ao limite quando o que é capaz de aproximar os casos é meramente o tema, ou assunto geral, neles tratado. Aqui, assim como nos casos anteriores, há mais espaço para disfuncionalidades no processo de justificação de decisões.

O ônus básico de trabalho com precedentes envolve considerações sobre semeIhanças entre os fatos do caso atual e do caso precedente. Se se concebe um precedente como a fonte de uma regra de decisão, os fatos do caso decidido são importantes para a identificação do suporte fático ou âmbito de incidência da norma que se extrai do julgado. Nesse cenário, a extração da consequência aplicada no caso precedente ao caso atual depende da aferição das propriedades factuais previamente selecionadas pela decisão tomada na questão que se decide agora. Estando elas presentes, a consequência se extrai dedutivamente. Pensando, por outro lado, em precedentes como referências para o desenvolvimento de raciocínios analógicos, sobretudo a partir dos exemplos que fornecem para o enfrentamento de problemas futuros ${ }^{55}$, da mesma forma o ponto de partida para a aplicação está na justificação de que o caso atual é semelhante, nas propriedades relevantes, ao caso precedente ${ }^{56}$. Não sendo esse o caso, é possível distinguir. Independentemente da concepção de que se parta para justificar o tipo de raciocínio exigido pela aplicação de precedentes, portanto, parece claro que o trabalho com decisões passadas requer algum tipo de análise minuciosa sobre as situações fáticas que parecem aproximar problemas concretos. Essa é a interpretação mais adequada, a meu

55 Para uma crítica à concepção de precedentes como regras e uma defesa de sua caracterização como exemplos, v. LEVENBOOK, Barbara, The meaning of a precedent. Legal Theory, vol. 6, n. 2, jun. 2000, especialmente p. 201 ss. Para a autora, a aproximação entre regras e precedentes é problemática sugere erros metafísicos e empíricos. Além disso, essa visão exclui verdades importantes sobre precedentes e o seu funcionamento. Isso ocorre, por exemplo, quando se pressupõe que regras possuem um âmbito de incidência fixado antecipadamente. Imaginar precedentes da mesma maneira retira deles a flexibilidade e a adaptabilidade para a solução de casos futuros próximos ao julgado anterior, mas não idênticos a ele.

56 Para Sunstein, em argumento que parece mais descritivo do que estrutural, a referência a um precedente como uma regra está geralmente associada à clareza com que ele se aplica a um caso atual. As semelhanças são tão evidentes e as diferenças inexistentes a ponto de se afirmar que o precedente vincula imediatamente. A referência a um precedente como analogia, porém, está mais associada a situações atuais que guardam semelhanças e diferenças com o caso precedente e que, exatamente por isso, exigem esforços de justificação baseadas na relevância das propriedades consideradas mais salientes para a aplicação ou para a distinção. V. SUNSTEIN, Cass R. Legal reasoning and political conflict. New York: Oxford University Press, 1996. p. 72. 
ver, do que estatui o artigo 489, §1º, V, do Código de Processo Civil, de acordo com o qual não se considera fundamentada a decisão que "se limitar a invocar precedente ou enunciado de súmula, sem identificar seus fundamentos determinantes nem demonstrar que o caso sob julgamento se ajusta àqueles fundamentos ${ }^{\prime \prime 57}$. O que pretende e verbaliza 0 legislador é que a aplicação de um precedente passe por considerações sobre o caso atual e os fundamentos que levaram à decisão do caso precedente, considerado em sua semelhança com o caso que se julga agora.

Fixadas essas premissas, a mera constatação de que casos se aproximam por envolverem debates sobre um mesmo tema ou assunto geral, captado geralmente por um conceito ou categoria jurídica abrangente, não parece suficiente para a justificação adequada da aplicabilidade de um precedente. Um exemplo, mais uma vez, pode ser útil.

No julgamento da ADPF 186, o Supremo apreciou a constitucionalidade de atos que instituíram sistema de reserva de vagas com base em critério étnico-racial ( $20 \%$ de cotas dessa natureza, para ser mais preciso) no processo de seleção de candidatos para ingresso na universidade de Brasília. Em seu voto favorável à constitucionalidade das medidas, o ministro Ricardo Lewandowski, relator da ação, indica alegados precedentes por meio dos quais a corte já teria reconhecido a constitucionalidade de políticas de ação afirmativa. Em meio a diversas decisões, cita também o RMS $26.071^{58}$. Ocorre, no entanto, que o suposto precedente se mostra problemático no caso em pelo menos dois aspectos.

Em primeiro lugar, é questionável se a decisão poderia ser considerada autoritativamente vinculante. Isso porque, enquanto o recurso em mandado de segurança foi julgado pela primeira turma do Supremo, a arguição de descumprimento de preceito fundamental foi (e é) julgada e processada originalmente pelo plenário da corte. Por esse motivo, não haveria como se alegar força de vinculação horizontal (já que o alegado precedente não é produto de uma decisão do mesmo órgão jurisdicional que precisa decidir o caso atual) nem vertical (já que, se a vinculação nessa hipótese decorre de relações de hierarquia, parece difícil sustentar que o pleno do Supremo estaria vinculado por uma das suas turmas) da decisão. Restaria, assim, considerar o RMS 26.071, no máximo, como uma decisão pretérita da corte que poderia exercer função persuasiva para o reforço da argumentação substantiva desenvolvida pelo plenário na ADPF 186.

Em segundo lugar, contudo, é também problemático o caráter de precedente mesmo persuasivo - do RMS 26.071 para a solução da ADPF 186 por razões metodológicas. Isso porque, excluída a hipótese de se considerar qualquer decisão anterior da corte

57 BRASIL. Lei no 13.105, de 16 de março de 2015. Código de Processo Civil. Brasília, DF: Presidência da República, 16 mar. 2015. Disponível em: http://www.planalto.gov.br/ccivil_03/_ato2015-2018/2015/lei/l13105. htm. Acesso em: 22 nov. 2019

58 BRASIL. Supremo Tribunal Federal (1. Turma). Recurso Ordinário em Mandado de Segurança 26.071-1/ DF. Concurso Público. Candidato portador de deficiência visual. Ambliopia. Reserva de Vaga. Inciso VIII do art.37 da Constituição Federal. $\S 2^{\circ}$ do art. $5^{\circ}$ da Lei ${ }^{\circ}$ 8.11/90. Lei $n^{\circ} 7.853 / 89$. Decretos n. ${ }^{\circ}$ s 3.298/99 e 5.296/2004. Recorrente: José Francisco de Araújo. Recorrido: Tribunal Superior do Trabalho. Relator: Min. Carlos Britto, 13 de novembro de 2007, p. 56. Disponível em: http://redir.stf.jus.br/paginadorpub/paginador.jsp?docTP=AC\&docID=506599. Acesso em: 21 nov. 2019. 
rigorosamente como um de seus "precedentes" aplicáveis para a fundamentação de decisões em quaisquer casos presentes, a caracterização de um julgado como precedente aplicável do Supremo dependeria, como dito, de aproximações factuais entre o caso atual e o caso pretérito. Sem isso, qualquer decisão poderia ser considerada, no limite, precedente para a decisão de qualquer caso. À luz dessa premissa, observada a questão de fato sob discussão no RMS, a sua aplicação à ADPF 186 se torna de difícil justificação. Isso porque o suposto precedente tratava da possibilidade de candidato portador de ambliopia "concorrer, na condição de portador de deficiência, a uma das vagas abertas pelo edital de concurso público para provimento de cargo de Técnico Judiciário no (...) Tribunal Superior do Trabalho"59. Como se nota, tais fatos são muito distantes daqueles apreciados na ADPF 186, que cuidava de políticas de cotas étnico-raciais para ingresso em uma universidade.

É certo que existe um ponto de contato entre os casos. Ambos se aproximam tematicamente ao tratarem de políticas de ação afirmativa. Esse, na verdade, é exatamente o ponto de interseção entre os julgados na construção do ministro Lewandowski, que, em seu voto, reconhece que "o Supremo Tribunal Federal, em diversas oportunidades, admitiu a constitucionalidade das políticas de ação afirmativa"60. Seria tal afirmação, porém, suficiente para a aplicação de um precedente? O tema geral, de fato, parece ser o único ponto de contato entre o julgado passado e o caso atual. Para além dos problemas já levantados relacionados à vinculação autoritativa ou substantiva, enquanto na ADPF 186 o que estava em jogo era a constitucionalidade de uma política específica de ação afirmativa, o que se discutia no RMS 26.071 era a operacionalização de outra. Os casos, portanto, parecem suficientemente diferentes para que se possa afirmar haver um elevado ônus de argumentação não superado para que a aplicabilidade do precedente para a solução do debate jurídico a respeito da constitucionalidade da política de cotas estabelecida pela UnB pudesse ser considerada justificada à luz do raciocínio do ministro.

\section{O RECURSO A TESES GERAIS DESVINCULADAS DO CASO DECIDIDO}

Outro tipo de aplicação aparentemente comum de um alegado precedente no Supremo Tribunal Federal se limita à menção de uma passagem que faz parte do raciocínio

59 BRASIL. Supremo Tribunal Federal (1. Turma). Recurso Ordinário em Mandado de Segurança 26.071-1/ DF. Concurso Público. Candidato portador de deficiência visual. Ambliopia. Reserva de Vaga. Inciso VIII do art.37 da Constituição Federal. $\S 2^{\circ}$ do art. $5^{\circ}$ da Lei $n^{\circ}$ 8.11/90. Lei $n^{\circ} 7.853 / 89$. Decretos n`s 3.298/99 e 5.296/2004. Recorrente: José Francisco de Araújo. Recorrido: Tribunal Superior do Trabalho. Relator: Min. Carlos Britto, 13 de novembro de 2007, p. 1. Disponível em: http://redir.stf.jus.br/paginadorpub/paginador.jsp?docTP=AC\&docID=506599. Acesso em: 21 nov. 2019.

60 BRASIL. Supremo Tribunal Federal (1. Turma). Recurso Ordinário em Mandado de Segurança 26.071-1/ DF. Concurso Público. Candidato portador de deficiência visual. Ambliopia. Reserva de Vaga. Inciso VIII do art.37 da Constituição Federal. $\S 2^{\circ}$ do art. $5^{\circ}$ da Lei n 8.11/90. Lei ${ }^{\circ} 7.853 / 89$. Decretos nº 3.298/99 e 5.296/2004. Recorrente: José Francisco de Araújo. Recorrido: Tribunal Superior do Trabalho. Relator: Min. Carlos Britto, 13 de novembro de 2007, p. 1. Disponível em: http://redir.stf.jus.br/paginadorpub/paginador.jsp?docTP=AC\&doCID=506599. Acesso em: 21 nov. 2019. 
desenvolvido na solução do caso decidido (uma parte da sua ratio decidendi, portanto) como parte da construção da fundamentação da decisão do caso atual. Neste contexto, a utilidade do precedente decorre da sua aptidão para fornecer razões para embasar o desfecho do novo caso, no que se exprime, mais uma vez, o seu uso persuasivo. O raciocínio de fundo parece ser: se for possível atribuir à solução do caso atual as mesmas razões que sustentaram a decisão do caso anterior, ou mesmo parte delas, justifica-se a aplicação do precedente. Se é esse o fundamento, parece, portanto, questionável dizer que a vinculação se dá por razões autoritativas nessa hipótese. Em vez de o precedente exercer pressão para a solução do caso atual pelo fato de ser uma manifestação de uma autoridade judicial, ele se torna, na verdade, fonte de fundamentos - talvez mais fortes, admite-se, do que o recurso, por exemplo, a um texto doutrinário, porque atrelados a uma decisão institucional - para a solução de problemas futuros. Com isso, o que existe é o apelo ao precedente para a justificação substantiva do caso atual. E, mais uma vez, volta-se ao dilema sobre os motivos que justificam a observância de precedentes: a autoridade ou a correção da decisão.

O problema da pretensa vinculação apenas por fragmentos das razões de decidir está no pressuposto de que a aplicação de um precedente exige o enfrentamento de todas as circunstâncias do caso atual. Um olhar particularista para o problema do presente cria um cenário em que o decisor estabelece uma interlocução com o precedente com o objetivo de decidir cada caso como se ele estivesse sendo julgado pela primeira vez. Um juízo menos complexo orientado na aplicação de uma regra que já previamente seleciona os aspectos relevantes do mundo para fins de extração da resposta jurídica para um caso atual ou na busca pela justificação das relações de semelhança entre os fatos dos casos em típico raciocínio analógico passa a ser insuficiente nesse modelo, que parece exigir como complemento permanente a aferição da adequação das mesmas razões de fundo do precedente para a sustentação do resultado para o caso atual. A solução do precedente não é tratada, após a sua identificação, como um dado, mas como o produto de um processo construtivo permanentemente aberto que incentiva diálogos do decisor presente com os fundamentos da decisão passada até a justificação da convergência entre os julgados. Se o precedente, por exemplo, foi construído em torno de uma ponderação de princípios, o recurso no presente aos fundamentos da decisão passada requer a confirmação de que, no caso atual, a mesma relação de prioridade afirmada no caso precedente se justifica - o que é, teoricamente, bastante questionável ${ }^{61}$. Nesse universo, os raciocínios de aplicação, distinção e superação de precedentes parecem se confundir, porque todos parecem pressupor o mesmo tipo de apreciação holística das características do caso atual até a sua decisão.

\footnotetext{
61 Essa é uma decorrência, para Alexy, da lei de colisão. De acordo com ela, o resultado de uma colisão de princípios leva ao estabelecimento de uma regra de preferência condicionada entre as normas, que fixa o resultado a ser aplicado para casos futuros que (i) envolvam os mesmos princípios em relação de tensão e (ii) compartilhem com o caso inicial características semelhantes. Na teoria dos princípios, a lei de colisão é a base para se sustentar a compatibilidade entre o trabalho com princípios jurídicos e a observância de precedentes. Por sua causa, trabalhar com princípios não significa ponderar sempre. V. a respeito da lei de colisão, ALEXY, Robert. Theorie der Grundrechte. Frankfurt a.M.: Suhrkamp, 1985, p. 84.
} 
O principal efeito dessa sobreposição de raciocínios está na dificuldade de identificação do papel efetivamente desempenhado pelo precedente para a solução de um caso. Se um julgado se limita a funcionar como fonte de argumentos para a solução de novos problemas, como é possível falar em força de vinculação? Em um caminho possível, a sustentação dessa força vinculante dependeria do reconhecimento de um caráter autoritativo qualificado das razões apresentadas em julgados passados relativamente a outras fontes disponíveis de justificação, como a dogmática jurídica, para a sustentação de soluções para casos futuros. E isso poderia ser feito a partir de empreendimentos intelectuais bastante distintos. Tanto uma teoria normativa da argumentação jurídica ${ }^{62}$ como uma teoria descritiva sobre a identificação de fontes do direito e de sua força em uma específica ordem jurídica ${ }^{63}$ se apresentariam como promissores candidatos. Mas, mesmo assim, qualquer investida ainda teria que passar pela importância, ou não, da aproximação factual entre os casos para a aplicação adequada de trechos das razões de decidir do caso precedente.

A prática decisória do Supremo, porém, não parece exigir esse esforço. Uma das consequências de se vincular a aplicação de precedentes a trechos da fundamentação da decisão passada está no aumento da dificuldade para se restringir o uso meramente estratégico ou aleatório de passagens esparsas de decisões como razões contextuais plenamente disponíveis para a sustentação de qualquer argumento. Sob essa perspectiva, se qualquer trecho de fundamentação pode ser um "precedente", o Supremo possui uma infinidade de fontes de justificação. Com isso, em vez de precedentes constrangerem o processo decisório, limitando as possibilidades de justificação - ou criando ônus especiais de argumentação para fundamentar a sua revisão -, eles terminam, na prática, funcionando como oportunidades para a sustentação de qualquer resultado ${ }^{64}$.

Como exemplo, é possível citar o recurso a precedentes no julgamento do HC 127.186/PR. Na verdade, o recurso a uma única decisão anterior. Como já tive a oportunidade de apontar, frases soltas do HC 95.290/SP foram evocadas por ministros diferentes para embasarem decisões em sentidos opostos ${ }^{65}$. Descontextualizadas, as teses gerais evocadas foram usadas na costura de argumentos favoráveis e contrários ao deferimento do HC 127.186/PR. Para o ministro Celso de Mello, a parte relevante do precedente era a que reconhecia que "a prisão cautelar (...) não objetiva infligir punição àquele que sofre a sua decretação, mas destina-se, considerada a função cautelar que lhe é inerente, a atuar

\footnotetext{
62 ALEXY, Robert. Theorie der juristischen Argumentation. Frankfurt a.M.: Suhrkamp, 1978, p. 399 ss.

63 Essa, a partir da proposta de Hart desenvolvida em "O Conceito de Direito", pode ser uma teoria que atribui a um parâmetro de justificação o caráter de fonte do direito e define a sua importância para o processo de justificação de decisões em função do que as autoridades oficiais responsáveis por dizer o que é o direito em certa comunidade dizem sobre as fontes de justificação e a sua relevância. A construção é feita a partir do papel desempenhado pela regra de reconhecimento para a identificação dos critérios de validade definidos em uma determinada sociedade. V. a respeito HART, H.L.A. The Concept of Law. 2. ed. New York: Oxford University Press, 1994, p. 100 ss.

64 LEAL, Fernando. Uma jurisprudência que serve para tudo. Jota, em 12 mai 2015. Disponível em: www.jota. info/opiniao-e-analise/artigos/uma-jurisprudencia-que-serve-para-tudo-12052015. Acesso em: 21 nov 2019.

65 LEAL, Fernando. Uma jurisprudência que serve para tudo. Jota, em 12 mai 2015. Disponível em: www.jota. info/opiniao-e-analise/artigos/uma-jurisprudencia-que-serve-para-tudo-12052015. Acesso em: 21 nov 2019.
} 
em benefício da atividade estatal no processo penal"66. Com base nesse trecho da ratio decidendi do HC 95.290/SP, o ministro votou pela denegação da ordem. Para o ministro Teori Zavascki, contudo, foram consideradas partes cruciais do precedente as que assentavam teses como: "a prisão preventiva - enquanto medida de natureza cautelar - não pode ser utilizada como instrumento de punição antecipada do indiciado ou do réu" e "a prisão cautelar não pode apoiar-se em juízos meramente conjecturais"67. Essas razões gerais, que, assim como as mencionadas pelo ministro Celso de Mello, poderiam estar nas páginas de qualquer livro de processo penal, foram articuladas, desta vez, para sustentar o deferimento do pedido.

Como se nota, os fatos relevantes de cada um dos casos são irrelevantes para a aplicação do alegado precedente. Não há qualquer tentativa de aproximação dos casos e tampouco se leva a sério que os problemas concretos poderiam envolver pedidos de habeas corpus relacionados ao suposto cometimento de crimes diferentes ${ }^{68}$. Ficam apenas passagens soltas de argumentos jurídicos que permanecem úteis para a construção de diversas outras fundamentações - e, com elas, o esvaziamento da própria ideia de precedente, cuja utilidade ou irrelevância passa a depender, no limite, apenas das preferências de quem a eles recorre. Nessa caracterização, todas as palavras de qualquer decisão importam. Isso torna qualquer passagem de julgados pretéritos um precedente aplicável ao desfecho de qualquer caso. Ao mesmo tempo - e ironicamente -, porém, a dificuldade de se determinar o que é, de fato, relevante em uma decisão passada para fins de vinculação torna qualquer caso atual facilmente distinguível de um precedente potencialmente aplicável. Para tanto, basta que se localize uma tese geral em qualquer julgado capaz de criar, durante o processo de justificação, uma exceção aos fundamentos do suposto precedente aplicável. Se é certo que nenhum caso é idêntico ao outro e que, para o direito, nem toda semelhança, assim como nem toda diferença, é relevante ${ }^{69}$ (incluindo as semelhanças naturais entre objetos), a perda de referência, pela desconsideração dos fatos, sobre o que conta efetivamente como central para fins de aplicação de um precedente cria um ambiente em que a apreciação de relevância passa a depender exclusivamente da habilidade do decisor de construir a sua justificativa a partir de retaIhos disponíveis no estoque de decisões pretéritas da corte.

Do ponto de vista dinâmico, essa maleabilidade dos precedentes é um diagnóstico especialmente perigoso em um tribunal que consagra aos ministros ampla liberdade para, por meio de seus votos, justificarem as suas decisões como parte das posições passadas da corte, enovelando-as dentro de uma narrativa cuja construção se encontra plenamente sob o seu controle. Em outras palavras, o uso das razões de decidir como

66 DE MELLO FILHO, José Celso, 2015 apud LEAL, Fernando. Uma jurisprudência que serve para tudo, op. cit.

67 ZAVASCKI, Teori Albino, 2015 apud LEAL, Fernando. Uma jurisprudência que serve para tudo, op. cit.

68 Enquanto o que estava em jogo no HC 95.290/SP - o "precedente" evocado - eram os crimes de concussão e associação criminosa, no caso atual se apreciava o possível cometimento dos crimes de organização criminosa, corrupção ativa e lavagem de dinheiro.

69 SCHAUER, Frederick. Thinking like a lawyer: a new introduction to legal reasoning. Cambridge: Harvard University Press, 2009, p. 45 e 48. 
precedentes amplia ainda mais o espaço da corte e de seus ministros para a institucionalização da sua própria versão da história do processo decisório do tribunal. Com isso, o que o recurso a precedentes deveria significar em termos de estabilidade, dilui-se em contingência e variabilidade.

\section{TODA DECISÃO É UM PRECEDENTE “DO SUPREMO"?}

Até este momento foram explorados problemas prioritariamente conceituais e metodológicos relacionados à identificação e à operacionalização de decisões passadas como precedentes da corte. Se as ementas são capazes de comunicar o que foi decidido, se todo e qualquer trecho da decisão (seja dictum, seja parte da ratio decidendi) pode ser considerado um precedente do Supremo ou se a aproximação meramente temática é suficiente para justificar a aplicação de precedentes são questões complexas cujos efeitos práticos sobre o processo decisório do tribunal tanto (i) facilitam o encontro de "precedentes" para justificar praticamente qualquer decisão, quanto (ii) dificultam a compreensão de "precedentes" como limites.

Ao lado desse conjunto de problemas há, porém, também desafios institucionais para a compreensão do que significa para os ministros um precedente da corte. O tipo de dificuldade que se pretende explorar já foi anteriormente antecipado quando foram apresentados os efeitos negativos do modelo seriatim para a construção de ementas e, especialmente, problematizou-se se a decisão da primeira turma no RMS 26.071/DF poderia ser considerada um precedente para a decisão da ADPF 186, julgada pelo plenário. Afinal, uma decisão de uma turma pode exercer força de vinculação sobre o plenário? Se se considera que o STF é uma corte que se organiza em torno do pleno, das turmas e dos excepcionais poderes que os ministros individualmente possuem para decidir, seria possível ainda perguntar (i) se a decisão de uma turma pode vincular outra turma ou o plenário e, ainda, se (ii) uma decisão monocrática pode ser considerada um precedente do Supremo. Se o que se pretende saber para fins de funcionamento da prática judicial é quem está vinculado no Supremo (para fins de vinculação horizontal) e por ele (quando se fala em vinculação vertical), uma questão prejudicial para a sua devida resposta é o que conta como um precedente da corte.

A prática do tribunal, mais uma vez, pouco ajuda, na medida em que é possível encontrar exemplos de todas as dificuldades que desafiam construções teóricas sobre a definição e a força de vinculação de precedentes. O caso mencionado sobre as relações entre o RMS 26.071/DF e a ADPF 186 é uma instanciação do que se poderia chamar de uma tentativa de vinculação vertical às avessas: evoca-se a decisão do órgão jurisdicional "inferior" para exercer pressão sobre o órgão jurisdicional "superior"70. A decisão no RE

\footnotetext{
70 Ainda que se possa discutir se a relação superior/inferior faz sentido em um tribunal marcado por competências bem demarcadas, a possibilidade de recurso de decisões das turmas para o plenário, quando juridicamente autorizada, e até o fato de a turma ser composta apenas por apenas parte de todo o pleno sugerem uma ascendência do plenário sobre a turma, ou a inexistência de relações de subordinação - mas nunca o contrário. De qualquer forma, ainda que não se considere existir relação hierárquica, o simples fato de serem órgãos
} 
717.290/Agr, julgado pela primeira turma, exprime, por sua vez, o esforço de aplicação de uma decisão de uma turma como precedente aplicável à decisão da outra. No caso atual, discutia-se a possibilidade de ajuizamento em face de qualquer ente da Federação de ação cujo objeto era tratamento custoso de saúde. Na decisão, o ministro Fux reconhece a solidariedade entre os entes federativos na matéria e cita, como precedente aplicável, o RE 716.777-AgR/RS, julgado pela segunda turma. Nos dois exemplos, como já adiantado, permanece discutível se as decisões passadas mencionadas pelos ministros podem ser consideradas precedentes aplicáveis com alguma força de vinculação para a solução dos casos atuais, na medida em que não foram tomadas pelo mesmo órgão decisor. Além disso, é igualmente questionável até que ponto é possível considerar essas decisões como "precedentes do Supremo Tribunal Federal".

A ilustração mais contraintuitiva dessas dificuldades, porém, está no emprego de uma decisão de um único ministro como representativa de um precedente da corte. Esse é um fenômeno especialmente possível em um tribunal cuja dinâmica interna garante espaços muito amplos para o exercício de poderes individuais "sem a participação do plenário ou até mesmo contra ele"71. Referenciada como "ministrocracia"72, essa realidade coloca em xeque a suficiência de certas categorias usadas tradicionalmente para a compreensão da atuação do Supremo Tribunal Federal na democracia brasileira. Como complemento de empreendimentos intelectuais destinados ao conhecimento da atuação coletiva da corte e de estudos sobre a sua expansão como instituição ${ }^{73}$, o conceito e as construções teóricas que dele se seguem pretendem captar uma realidade mais complexa de funcionamento da corte, em que o "STF aloca de maneira individual e descentralizada uma série de poderes individuais de agenda, de sinalização e mesmo de decisão formal"74, sobretudo quando o tribunal é chamado a se pronunciar sobre conflitos políticos. Nesse universo, é possível que manifestações individuais dirimam definitivamente problemas jurídicos complexos e não antes enfrentados pelo tribunal, funcionando na prática, em consequência desse fato, como precedentes da instituição.

jurisdicionais diferentes, com competências e composições distintas seria suficiente para tornar difícil a tese de existência de qualquer relação de autoridade de um sobre o outro.

71 ARGUELHES, Diego Werneck; RIBEIRO, Leandro Molhano. Ministrocracia: O Supremo Tribunal individual e o processo democrático brasileiro. Novos Estudos CEBRAP, São Paulo, vol. 37, n. 01, jan./abr. 2018, p. 14. Disponível em: http://www.scielo.br/scielo.php?pid=S0101-33002018000100013\&script=sci_abstract\&tlng=pt. Acesso em: 21 nov. 2019.

72 ARGUELHES, Diego Werneck; RIBEIRO, Leandro Molhano. Ministrocracia: O Supremo Tribunal individual e o processo democrático brasileiro. Novos Estudos CEBRAP, São Paulo, vol. 37, n. 01, jan./abr. 2018, p. 30. Disponível em: http://www.scielo.br/scielo.php?pid=S0101-33002018000100013\&script=sci_abstract\&tlng=pt. Acesso em: 21 nov. 2019.

73 V. VIEIRA, Oscar Vilhena. Supremocracia. Revista Direito GV, São Paulo, vol. 4, n 2, p. 441-464, jul./dez. 2008. Disponível em: http://bibliotecadigital.fgv.br/ojs/index.php/revdireitogv/article/view/35159/33964. Acesso em: 22 nov. 2019.

74 ARGUELHES, Diego Werneck; RIBEIRO, Leandro Molhano. Ministrocracia: O Supremo Tribunal individual e o processo democrático brasileiro. Novos Estudos CEBRAP, São Paulo, vol. 37, n. 01, jan./abr. 2018, p. 27. Disponível em: http://www.scielo.br/scielo.php?pid=S0101-33002018000100013\&script=sci_abstract\&tlng=pt. Acesso em: 21 nov. 2019. 
Esse também é um problema já mapeado. Segundo Arguelhes e Molhano, "é possível observar no STF a utilização de decisões monocráticas como estratégia individual de construção de 'jurisprudência' ou 'precedentes' sem a mediação do colegiado"75. E o exemplo por excelência desse problema está na ADPF 45. Evocado no próprio Supremo, segundo dados da plataforma de referências do projeto "Supremo em Números" da FGV Direito Rio, em 241 decisões $^{76}$, o suposto precedente é um problema porque se limita a uma ementa construída por um único ministro - no caso, o relator, ministro Celso de Mello. Os autores citam diversos exemplos que evidenciam a incorporação da ADPF 45 no inventário de precedentes da corte. No mais claro deles, a ministra Ellen Gracie, no RE 559.646-AgR, afirmou que "o plenário [sic] do STF havia reconhecido, na ADPF 45, a possibilidade de controle judicial de políticas públicas previstas na Constituição"77. Considerando especificamente a vinculação vertical, não é igualmente difícil encontrar referências ao suposto precedente em decisões de outras cortes. No Recurso Especial 1.367.549/ MG, por exemplo, o ministro Humberto Martins, do Superior Tribunal de Justiça, antes de transcrever um trecho da ementa cunhada pelo ministro Celso de Mello sustentou: "[e]m decisão recente, e que pode ser considerada como um marco para a nova interpretação do princípio da separação dos Poderes, entendeu a Corte Suprema nos autos da ADPF-45 $(. . .)^{1178}$, o que evidencia o reconhecimento da decisão como resultante do processo decisório do Supremo, e não de apenas um dos seus integrantes.

A ADPF 45 e os demais exemplos mencionados adicionam à cesta de possibilidades de caracterização de decisões como "precedente do Supremo" novos elementos. Até este momento, a conclusão a que se chega é simples e impressionante: dentro e fora do Supremo, parece que qualquer pedaço de qualquer decisão de qualquer das suas competentes instâncias decisórias pode ser aplicado como precedente do tribunal.

\section{UM PRECEDENTE IMPOSSÍVEL}

A utilidade da ADPF 45 para denunciar o apelo pouco criterioso a manifestações da corte ou de seus ministros como "precedentes" não se esgota, porém, no fato de ela não significar mais do que uma ementa elaborada por um único ministro. Um olhar mais atento para as palavras do ministro Celso de Mello permite facilmente concluir que a

\footnotetext{
75 ARGUELHES, Diego Werneck; RIBEIRO, Leandro Molhano. O Supremo Individual: mecanismos de atuação direta dos Ministros sobre o processo político. Revista Direito, Estado e Sociedade, n. 46, jan./jun. 2015 , p. 141. Disponível em: http://direitoestadosociedade.jur.puc-rio.br/media/Artigo5_46.pdf. Acesso em: 21 nov. 2019.

76 A pesquisa foi realizada em 14 nov. 2019.

77 ARGUELHES, Diego Werneck; RIBEIRO, Leandro Molhano. O Supremo Individual: mecanismos de atuação direta dos Ministros sobre o processo político, Revista Direito, Estado e Sociedade, n. 46, jan./jun. 2015 , p. 144. Disponível em: http://direitoestadosociedade.jur.puc-rio.br/media/Artigo5_46.pdf. Acesso em: 21 nov. 2019.

78 BRASIL. Superior Tribunal de Justiça (2. Turma). Recurso Especial n 1.367.549/ MG. Processo Civil. Administrativo. Ação Civil Pública. Obrigação de fazer. Dano Ambiental. Implementação de Obra Pública. Usina de Reciclagem de Resíduos Sólidos. Ingerência do Poder Judiciário. Violação do princípio da separação e poderes. Inexistência. Violação ao art. 333, I, do CPC caracterizada. Recorrente: Ministério Público do Estado de Minas Gerais. Recorrido: Município de Uberlândia. Relator: Min. Humberto Martins, 02 de setembro de 2014, p. 13. Disponível em: https://ww2.stj.jus.br/websecstj/cgi/revista/REJ.cgi/lTA?seq=1299335\&tipo=0\&nreg=201101325135\&SeqCgrmaSessao=\&CodOrgaoJgdr=\&dt=20140908\&formato=PDF\&salvar=false. Acesso em: 21 nov. 2019.
} 
tradição criada na prática decisória de juízos e tribunais brasileiros pelo uso recorrente da ADPF 45 é baseada em um precedente impossível.

Independentemente das discussões a respeito (i) do caráter autoritativo ou persuasivo de um precedente, (ii) do papel desempenhado pelas suas partes fundamentais para fins de aplicação e (iii) de como se deve justificar a extração, para um caso atual, da solução dada para um caso anterior, parecem inexistir dúvidas em torno de uma característica de que deve gozar uma manifestação pretérita de uma autoridade oficial do direito para que possa ser considerada como um de seus precedentes: é preciso que haja uma decisão. Em curtos meios, sem decisão, não há precedente. Se isso pode ser considerado verdadeiro, a impossibilidade de definir a ementa da ADPF 45 como um precedente (do Supremo ou do ministro, persuasivo ou autoritativo) decorre do simples fato de o pedido da ação jamais ter sido julgado. Para quem chega até o final da longa ementa, é fácil perceber que a última manifestação do ministro Celso de Mello encerra a ação, considerada prejudicada "em virtude da perda superveniente de seu objeto"79. Assim, o que a menção à ementa da ADPF 45 significa para a construção de uma decisão não se diferencia substancialmente da transcrição de palavras que poderiam estar publicadas em um trabalho acadêmico assinado pelo próprio ministro. $\mathrm{O}$ que se pretende com o seu uso deveria se limitar, no máximo, a tentar constrangê-lo a partir de demandas por consistência com as suas próprias ideias. E isso está bem distante de reconhecer o texto como um precedente válido da corte.

\section{QUANDO A CORTE ACERTA: ACASO OU USO ESTRATÉGICO?}

Os problemas apontados até este momento são capazes de sustentar a hipótese de que o trabalho com precedentes no Supremo é contestável. Os exemplos, muitos deles de tom até anedótico, sequer podem, sem um exame mais rigoroso, ser considerados necessariamente representativos da jurisprudência do $\mathrm{STF}^{80}$. A conclusão de que o tribunal tende a cometer frequentemente os equívocos apresentados nas seções anteriores informa, na verdade, intuições que poderiam funcionar como hipóteses a serem testadas empiricamente em um universo representativo de decisões da corte. E não há nada de excepcional em reconhecê-lo. O ponto, nada obstante, é que, assim como é possível identificar recursos controversos a supostos precedentes do Supremo, é também possível encontrar decisões do tribunal justificadas com base no recurso adequado a julgados passados. Em curtos meios, o Supremo também acerta quando operacionaliza seus precedentes. Corroborando essa conclusão, em seu estudo sobre o uso de decisões

\footnotetext{
79 V. PICININ, Graziela Maria. Informativo STF n ${ }^{345}$. Brasília: Supremo Tribunal Federal, 26-30 abr. 2004. Disponível em: http://www.stf.jus.br/arquivo/informativo/documento/informativo345.htm. Acesso em: 22 nov. 2019

80 A análise de Vojvodic, na verdade, indica que os problemas apontados são pouco comuns na jurisprudência do Supremo. Para a autora "(...) a analogia estrita é o modo de utilização de precedentes que mais se observou na aplicação de precedentes, afastando argumentos como os que afirmam ser o juiz brasileiro completamente obtuso na aplicação de precedentes". V. VOJVODIC, Adriana. Precedentes e argumentação no Supremo Tribunal Federal: entre a vinculação ao passado e a sinalização para o futuro. 2012. Tese (Doutorado em Direito) - Faculdade de Direito, Universidade de São Paulo, São Paulo, 2012. Disponível em: https://www.teses.usp.br/teses/ disponiveis/2/2134/tde-27092012-094000/publico/tese_Adriana_Vojvodic.pdf. Acesso em: 28 fev. 2020, p. 200.
} 
passadas pelo STF, Vojvodic menciona como em sua análise qualitativa a reiteração de posicionamentos passados condensados em precedentes está vinculada, com alguma frequência, a casos muito próximos. Isso ocorre, por exemplo, "quando estão estabelecidas algumas premissas dos casos em julgamento - como questões processuais, matérias formais", situações em que "a aplicação de precedentes é feita com base exclusivamente no que ficou decidido neles, não havendo a necessidade de uma construção interpretativa de seus elementos argumentativos" 81 . A autora chega a caracterizar essa "forma de aplicar precedentes" como "fortemente vinculada" 82 , o que sugere o recurso autoritativo - e não meramente persuasivo - a julgados passados.

Um exemplo aparentemente inquestionável de aplicação consistente de um precedente se extrai da apreciação da constitucionalidade das chamadas "brigas de galo". A autorização estadual dessa prática, em pelo menos duas oportunidades (ADIs 1.856/RJ e $2.514 / \mathrm{SC}$ ), foi declarada inconstitucional a partir basicamente da sua semelhança com a prática cultural conhecida como "farra do boi", julgada, pela segunda turma da corte, incompatível com a Constituição Federal no RE 153.351/SC. Se, recorrendo à síntese de Conrado Hübner Mendes, a regra de decisão que se pode extrair do acórdão é "prática cultural que exponha, sistematicamente, animais à crueldade, é inconstitucional"83, o trabalho da corte no julgamento das brigas de galo deveria se limitar basicamente a aferir se os termos que definem o âmbito de incidência do precedente estavam presentes no caso. E, no geral, assim se comportaram os ministros. O raciocínio exigido para tanto era tão pouco complexo que o voto do ministro Eros Grau, relator da ADI 2.514/SC, endossado sem argumentos concorrentes pelos demais ministros do Supremo, possui suficientes duas páginas. Assim, ainda que, do ponto de vista formal, seja possível questionar se uma decisão de turma é capaz de vincular o plenário, metodológica e substantivamente a aplicação do alegado precedente, dada a semelhança entre os casos, é precisa.

Entre tantas categorias diferentes de problemas relacionados ao manejo de decisões passadas da corte, fica, porém, a possibilidade de se questionar se os eventuais acertos não são (i) meramente circunstanciais ou (ii) mesmo produtos de agir estratégico dos ministros ${ }^{84}$. Na primeira hipótese, o acerto pode ser fruto do acaso ou, em uma leitu-

81 VOJVODIC, Adriana. Precedentes e argumentação no Supremo Tribunal Federal: entre a vinculação ao passado e a sinalização para o futuro. 2012. Tese (Doutorado em Direito) - Faculdade de Direito, Universidade de São Paulo, São Paulo, 2012. Disponível em: https://www.teses.usp.br/teses/disponiveis/2/2134/tde-27092012094000/publico/tese_Adriana_Vojvodic.pdf. Acesso em: 28 fev. 2020, p. 174.

82 VOJVODIC, Adriana. Precedentes e argumentação no Supremo Tribunal Federal: entre a vinculação ao passado e a sinalização para o futuro. 2012. Tese (Doutorado em Direito) - Faculdade de Direito, Universidade de São Paulo, São Paulo, 2012. Disponível em: https://www.teses.usp.br/teses/disponiveis/2/2134/tde-27092012094000/publico/tese_Adriana_Vojvodic.pdf. Acesso em: 28 fev. 2020, p. 181.

83 MENDES, Conrado Hübner. Lendo uma decisão: obiter dictum e ratio decidendi. Racionalidade e retórica na decisão. Sociedade Brasileira de Direito Público, 2010, p. 8. Disponível em: http://www.sbdp.org.br/arquivos/ material/19_Estudo\%20dirigido\%20-\%20Ratio\%20decidendi\%20e\%20obter\%20dictum\%20-\%20Conrado\%20 Hubner\%20Mendes.pdf. Acesso em: 13 nov. 2019.

84 O uso estratégico de precedentes é problema comumente denunciado na prática advocatícia e mesmo na construção de trabalhos acadêmicos, que selecionam decisões de maneira enviesada para a sustentação de pontos de vista específicos. V. DIAS NETO, Theodomiro; BUENO, Cassio Scarpinella; FORGIONI, Paula. As áreas do direito e especificidades em matéria de pesquisa. In: NOBRE, Marcos et al. O que é pesquisa em Direito?, São 
ra mais otimista, apenas produto da inexistência de dúvidas sobre o compartilhamento de claras propriedades relevantes entre o caso atual e o precedente desacompanhadas de alegação de qualquer diferença significativa entre os dois. Nessa última leitura, a aplicação correta é produto do reconhecimento de que as situações de fato são praticamente idênticas a partir de um julgado (o precedente) que possibilita a identificação precisa da resposta a ser dada e das circunstâncias de fato consideradas necessárias para a sua aplicação ${ }^{85}$. Nessas situações, em que, nos EUA, "advogados e juízes costumam dizer que o precedente 'está firme no chão"'16, ${ }^{\prime \prime}$ precedentes parecem funcionar como boas fontes de razões para a justificação de decisões da corte em casos que poderiam ser considerados fáceis ${ }^{87}$.

Na segunda hipótese, por sua vez, a observância de precedentes poderia se dar pela conveniência dos seus benefícios pontuais para evitar indisposições político-institucionais na própria corte ou fora dela. Isso vale tanto para a instituição em si como para os seus ministros. Possíveis motivos para esse comportamento poderiam, por exemplo, estar na percepção de que o contexto não é favorável para a reversão do precedente (por receio de reação imediata do Legislativo capaz de derrotar substantivamente a decisão ou, por meio de alterações no desenho, de redução de competências da corte) ou na falta de interesse de assumir o ônus de apresentar manifestação dissidente em caso em que já se sabe, ou é bastante plausível, que os demais integrantes do colegiado irão aderir ao que já foi julgado. No primeiro caso, a corte age estrategicamente tentando evitar um esperado efeito backlash de sua manifestação se socorrendo da própria jurisprudência para se declarar atada a um dever de consistência no tempo para não ter que tomar decisões politicamente polêmicas ${ }^{88}$. No segundo, o agir estratégico pode ser

Paulo: Quartier Latin, 2005, p. 184. V. também a alegação de uso inadequado de precedente pelo Procurador Geral da República em: CANÁRIO, Pedro. Precedente usado por Janot em caso de impedimento contraria sua tese. Revista Consultor Jurídico, 09 mai. 2017. Disponível em: https://www.conjur.com.br/2017-mai-09/alegar-suspeicao-gilmar-janot-usa-precedente-contraria. Acesso em: 21 nov. 2019.

85 Não se descarta que a dificuldade de se encontrar casos atuais que se amoldem facilmente a um precedente pode também decorrer de características apontadas anteriormente do modelo seriatim em torno do qual se organiza o próprio processo decisório da corte. Nesse particular, a adoção de um modelo decisório em que a manifestação da corte é o resultado da soma de manifestações individuais possibilita que, na prática, nem sempre seja simples identificar o que a corte decidiu e/ou por que a decisão foi tomada. Quando a própria decisão ou os seus fundamentos não são claros, a dificuldade de aplicar um precedente a um caso atual ou distinguir este último do precedente se torna tarefa complexa. Sobre esse problema com exemplos extraídos da prática decisória do Supremo v. VOJVODIC, Adriana de Moraes; MACHADO, Ana Mara França; CARDOSO, Evorah Lusci Costa. Escrevendo um romance, primeiro capítulo: precedentes e processo decisório no STF. Revista Direito GV, São Paulo, vol. 5, n. 1, p. 21-44, jan./jun. 2009. Disponível em: http://www.scielo.br/pdf/rdgv/v5n1/a02v5n1. Acesso em: 21 nov. 2019.

86 SCHAUER, Frederick. Thinking like a lawyer: a new introduction to legal reasoning. Cambridge: Harvard University Press, 2009, p. 45.

87 O julgamento da ADI 4893/CE, porém, pode tanto ratificar a tese como colocá-la em xeque. Isso porque na ação, em que se discutia a constitucionalidade da prática cultural denominada "vaquejada", enquanto seis ministros (a maioria) entenderam ser ela inconstitucional por, entre outras razões, guardar semelhanças com os casos da "farra do boi" e das "brigas de galo", cinco outros distinguiram o caso atual do caso precedente.

88 Para exemplos de backlash a decisões da Suprema Corte americana e o comportamento estratégico dos julgadores em certos casos v. KLARMAN, Michael. Courts, Social Change, and Political Backlash. Philip A. Hart Memorial Lecture, n. 2, 2011. Disponível em: https://scholarship.law.georgetown.edu/cgi/viewcontent.cgi?article $=1001 \&$ context=hartlecture. Acesso em: 22 nov. 2019. 
individual e explicado, por exemplo, pela dinâmica de funcionamento da própria corte e pela pouca influência do voto dissidente sobre a cadeia de precedentes que se forma com a decisão passada e o julgamento do caso atual ${ }^{89}$. Essas são apenas hipóteses não exaustivas para sustentar o argumento geral de que a observância de um precedente não é necessariamente convergente com a posição substantiva que um ministro pode ter sobre a questão jurídica especificamente sob discussão, e tampouco que ela está sustentada pelas razões de fundo que justificam a aplicação de um precedente com o qual se discorde, como a igualdade, a segurança, a eficiência, a transparência, a previsibilidade ou a estabilidade do direito ${ }^{90}$. Ministros podem estar convencidos da necessidade de reversão de um precedente ou terem interesses em fazê-lo, mas podem optar por, ainda assim, aplicá-lo por razões que não são propriamente jurídicas, estejam elas relacionadas ao próprio caso atual ou ao impacto do julgado sobre a solução de outros problemas com ele relacionados.

A hipótese de agir estratégico poderia ser levantada no comportamento da ministra Rosa Weber no HC 152.752/DF, que tinha o ex-presidente Lula como paciente. A questão jurídica de fundo envolvia a possibilidade de início de execução da sanção penal após condenação em segunda instância, mas antes do trânsito em julgado da decisão. Reconhecidamente o voto mais aguardado do julgamento ${ }^{91}$, a ministra já teria dado "sinais trocados" sobre o desfecho do caso, o que lhe permitiria decidir tanto pelo provimento do habeas corpus como pela denegação da ordem. A ministra, por um lado, "foi contra a execução provisória de pena quando do julgamento no plenário sobre o tema, mas [por outro, já tinha] (...) se curvado à decisão da maioria e votado contra a concessão de HCs para condenados em segundo grau"92.

Em voto bem construído, a ministra negou o habeas corpus para o ex-presidente invocando a necessidade de observância dos precedentes da corte e um dever de colegialidade, considerado "imprescindível (isto é, necessário e suficiente) para o sistema, porquanto a individualidade dentro do tribunal, no processo decisório, tem um momento delimitado, a partir do qual cede espaço para a razão institucional revelada no voto majoritário da Corte ${ }^{\prime \prime 93}$. Apesar desse apelo à consistência, a ministra na parte final do

${ }_{89}$ V. nessa linha, ainda que a pesquisa não diga especificamente à Suprema Corte: FARHANG, Sean; WAWRO, Gregory. Institutional Dynamics on the U.S. Court of Appeals: Minority Representation under Panel Decision Making. The Journal of Law, Economics \& Organization, vol. 20, n. 2, p. 299-330, out. 2004.

90 SCHAUER, Frederick. Precedent. Stanford Law Review, vol. 39, No. 3, fev. 1987, p. 595-602. V. também BANKOWSKI, Zenon et al. Rationales for precedent. In: MACCORMICK, D. Neil; SUMMERS, Robert S. (Org). Interpreting precedents: a comparative study. Aldershot: Ashgate/Dartmouth, 1997, especialmente p. 481-493.

91 V. SOUZA, André de; MARIZ, Renata; BRESCIANI, Eduardo. Rosa Weber nega habeas corpus a Lula, e deve ser rejeitado. O Globo, Brasília, 04 abr. 2018. Disponível em: https://oglobo.globo.com/brasil/rosa-weber-nega-habeas-corpus-lula-pedido-deve-ser-rejeitado-22557114. Acesso em: 22 nov. 2019.

92 V. TEIXEIRA, Matheus; FALCÃO, Márcio; CARNEIRO, Luiz Orlando. Rosa Weber e os sinais trocados no julgamento do HC de Lula. Jota, 22 mar. 2018. Disponível em: https://www.jota.info/stf/rosa-weber-e-os-sinais-trocados-no-julgamento-do-hc-de-lula-22032018. Acesso em: 22 nov. 2019.

93 BRASIL. Supremo Tribunal Federal (plenário). Habeas Corpus 152.752/PR. Matéria Criminal. Execução Provisória da pena. Impetração em substituição a Recurso Ordinário constitucional. Cognoscibilidade. Ato reputado coator compatível com a jurisprudência do STF. llegalidade ou abuso de poder. Inocorrência. Alegado caráter não vinculante dos precedentes desta Corte. Irrelevância. Deflagração da etapa executiva. Fundamentação específica. Desnecessidade. Pedido expresso da acusação. Dispensabilidade. Plausibilidade de teses veiculadas em 
voto fez questão de registrar a sua discordância com a posição substantiva do tribunal à qual demonstrava aderência no caso concreto. Segundo ela, a questão constitucional de fundo "há de ser revisitad[a] no exercício do controle abstrato de constitucionalidade"94. Em linha de coerência com essa sinalização, no julgamento das ADCs 43, 44 e 54, em que se discutia abstratamente o assunto, a ministra votou pela impossibilidade de se executar a sanção penal antes do trânsito em julgado da decisão condenatória.

As posições da ministra são coerentes entre si. Elas, na verdade, revelam a disposição em reconhecer como autoritatitvas - e não substantivas - as razões que embasam a sua vinculação a decisões passadas da corte no enfrentamento de casos concretos. Isso fica evidente quando a ministra expressa deferência a uma decisão com a qual, no mérito, diz explicitamente não concordar. Se, no entanto, o seu comportamento de sempre observar precedentes do plenário, mesmo que deles discorde, é frequente, só uma pesquisa metodologicamente rigorosa poderá atestar. Na eventualidade de a execução dessa agenda de pesquisa revelar inconsistências no tempo, a hipótese de agir estratégico ganha corpo. E esse agir não necessariamente está relacionado à realização de preferências pessoais. Ela pode, em uma leitura possível das manifestações da ministra, estar, inclusive, orientada na promoção de objetivos institucionais, como realçar a colegialidade da corte ou afiançar os seus compromissos com a segurança jurídica e a integridade da sua própria jurisprudência, o que contribuiria para reforçar a credibilidade do Supremo. Em qualquer caso, o que se destaca neste ponto é que a desorientação da prática decisória da corte permite sustentar não só o erro, mas também o agir estratégico como fundamento para o uso inconsistente ou consistente de precedentes no STF.

\section{CONCLUSÃO}

O resultado das análises desenvolvidas, ainda que não possa ser generalizado pela ausência de base empírica ampla, não sugere otimismo. Em vez de atuarem como limites, o que o Supremo costuma considerar seus "precedentes" pode garantir, na verdade, oportunidades quase infinitas de justificação para si e para os tribunais que decidem abaixo dele. Ademais, parece difícil sustentar nesse universo, em que (i) partes aleatórias de julgamentos passados podem ser selecionadas para a sustentação de qualquer resultado e (ii) nem sempre os fatos dos casos são considerados efetivamente relevantes para a aplicação dos alegados precedentes, que o Supremo se sinta vinculado pelo passado. E,

futuro Recurso Excepcional. Supressão de instância. Ordem denegada. Paciente: Luiz Inácio Lula da Silva. Impetrante: Cristiano Zanin Martins. Relator: Min. Edson Fachin, 04 de abril 2018. p. 198. Disponível em: http://redir.stf. jus.br/paginadorpub/paginador.jsp?docTP=TP\&docID=15132272. Acesso em: 22 nov. 2019.

94 BRASIL. Supremo Tribunal Federal (plenário). Habeas Corpus 152.752/PR. Matéria Criminal. Execução Provisória da pena. Impetração em substituição a Recurso Ordinário constitucional. Cognoscibilidade. Ato reputado coator compatível com a jurisprudência do STF. llegalidade ou abuso de poder. Inocorrência. Alegado caráter não vinculante dos precedentes desta Corte. Irrelevância. Deflagração da etapa executiva. Fundamentação específica. Desnecessidade. Pedido expresso da acusação. Dispensabilidade. Plausibilidade de teses veiculadas em futuro Recurso Excepcional. Supressão de instância. Ordem denegada. Paciente: Luiz Inácio Lula da Silva. Impetrante: Cristiano Zanin Martins. Relator: Min. Edson Fachin, 04 de abril 2018. p. 198. Disponível em: http://redir.stf. jus.br/paginadorpub/paginador.jsp?docTP=TP\&docID=15132272. Acesso em: 22 nov. 2019. 
mesmo quando isso acontece, fica como questão aberta, como sugerido, se a aderência ao precedente é genuína, casual ou meramente estratégica. Se, nesse cenário de interrogações, a vinculação vertical tende a se mostrar, na prática, disfuncional, especialmente quando se constata que tribunais inferiores tendem a lidar com os alegados precedentes do Supremo da mesma maneira que a própria corte utiliza os seus julgados passados, a vinculação horizontal soa um ideal irrealizável.

Isso não quer dizer que o passado decisório da corte não seja influente na solução de casos atuais. O Supremo cada vez mais evoca julgados pretéritos para sustentar as soluções que fixa para casos no presente. $E$, aparentemente, com certa frequência o faz bem ${ }^{95}$. Para lidar com questões repetitivas ou com casos que se revelem, mesmo que apenas ex post, muito semelhantes, essa jurisprudência de reiteração, como define López Medina ${ }^{96}$, mostra-se não somente adequada para a solução do caso atual, como útil para a percepção de continuidade e coerência no processo decisório da corte. No enfrentamento de problemas mais complexos e pouco usuais, contudo, (i) o apelo persuasivo a peças do estoque decisório do tribunal, (ii) o pouco cuidado com a aproximação factual entre o alegado precedente e o caso atual e (iii) a extrema amplitude do que possa ser considerado precedente da corte parecem criar uma realidade em que as virtudes tradicionalmente relacionadas à presença de uma prática estável de precedentes se diluem. Em vez de a utilização de precedentes na justificação de julgados contribuir para a promoção de segurança, igualdade e eficiência, seu uso retórico ou mal desenvolvido reduz a qualidade da justificação, aumenta desnecessariamente custos decisórios e cria desorientação.

Várias das dificuldades apontadas não são, entretanto, típicas apenas da realidade brasileira. Nos EUA, por exemplo, Segal e Spaeth sustentam empiricamente que os juízes da Suprema Corte, ao contrário do que parecia ser a intuição no país, não são influenciados pelos precedentes dos quais divergem ${ }^{97}$. Se há discordância com o passado, a prática mostra que ele é simplesmente invisibilizado e argumentos substantivos são desenvolvidos para criar o primeiro elo de uma nova corrente de precedentes na história institucional da corte.

A realidade problemática do processo decisório de uma corte suprema não elimina, porém, qualquer possibilidade de otimismo. O contraponto para a visão de que a prática de precedentes de um tribunal como o Supremo está bem distante da complexidade dos debates teóricos sobre o assunto e das prescrições desenvolvidas para justificar

\footnotetext{
95 VOJVODIC, Adriana. Precedentes e argumentação no Supremo Tribunal Federal: entre a vinculação ao passado e a sinalização para o futuro. 2012. Tese (Doutorado em Direito) - Faculdade de Direito, Universidade de São Paulo, São Paulo, 2012. Disponível em: https://www.teses.usp.br/teses/disponiveis/2/2134/tde-27092012094000/publico/tese_Adriana_Vojvodic.pdf. Acesso em: 28 fev. 2020, p. 200.

96 MEDINA, Diego López. El Derecho de los jueces. Bogotá: Legis, 2009, apud VOJVODIC, Adriana. Precedentes e argumentação no Supremo Tribunal Federal: entre a vinculação ao passado e a sinalização para o futuro. 2012. Tese (Doutorado em Direito) - Faculdade de Direito, Universidade de São Paulo, São Paulo, 2012. Disponível em: https://www.teses.usp.br/teses/disponiveis/2/2134/tde-27092012-094000/publico/tese_Adriana_Vojvodic. pdf. Acesso em: 28 fev. 2020, p. 168.

97 SEGAL, Jeffrey A.; SPAETH, Harold J. The influence of stare decisis on the votes of United States Supreme Court justices. American Journal of Political Science, vol. 40, n. 4, p. 971-1003, nov.1996.
} 
mecanismos de vinculação horizontal pode vir do caráter excepcional do próprio processo decisório de uma corte superior. Buscar consistência com o passado em um tribunal de cúpula ou em uma corte constitucional pode ser a fonte do problema. Como aponta Schauer, porque o acervo da Suprema Corte americana é dominado por casos de elevado impacto político ou profundo desacordo moral, ela deveria ser naturalmente considerada o último lugar para se encontrar traços de stare decisis ${ }^{98}$. Se o objetivo de qualquer investigação for aferir vinculações consistentes com o passado, talvez seja melhor olhar para outras cortes que enfrentam casos mais rotineiros e que, por isso, tendam a lidar bem menos com situações quase únicas.

É certo que o Supremo não é um tribunal que julga pouco e que só é instado a se manifestar sobre questões altamente complexas ${ }^{99}$. O tribunal, ao mesmo tempo em que enfrenta casos difíceis como uma corte constitucional, possui competências que o colocam na posição de foro especializado e é, sobretudo, também uma instância recursal ${ }^{100}$ abarrotada de problemas parecidos entre si ou com outros já julgados, às vezes diversas vezes, pela corte. Esse último aspecto, por um lado, coloca como problemas permanentes explicar por que a corte pode não possuir as condições normativas e institucionais necessárias para desenvolver uma prática estável de precedentes em qualquer concepção sobre essas fontes de decisão e por que, por isso, o reforço adequado da jurisprudência parece ser fruto do acaso ou, independentemente do acerto da menção de um caso passado para a solução de caso atual, produto de justificação inconsistente. Por outro lado, contudo, reconhecer que parte do trabalho do tribunal envolve o enfrentamento de questões muito singulares pode ser o ponto de partida para recalibrar certas expectativas que se possa ter sobre a possibilidade de se aproximar, na realidade, o que se espera do processo decisório do Supremo do que ele efetivamente pode oferecer.

\section{REFERÊNCIAS}

ALEXY, Robert. Theorie der Grundrechte. Frankfurt a.M.: Suhrkamp, 1985.

ALEXY, Robert. Theorie der juristischen Argumentation. Frankfurt a.M: Suhrkamp, 1978.

ARGUELHES, Diego Werneck; RIBEIRO, Leandro Molhano. Ministrocracia: O Supremo Tribunal individual e o processo democrático brasileiro. Novos Estudos CEBRAP, São Paulo, vol. 37, n. 01, p. 12-32, jan./abr. 2018. Disponível em: http://www.scielo.br/scielo.php?pid=S010133002018000100013\&script=sci_abstract\&tlng=pt. Acesso em: 21 nov. 2019.

ARGUELHES, Diego Werneck; RIBEIRO, Leandro Molhano. O Supremo Individual: mecanismos de atuação direta dos Ministros sobre o processo político. Direito, Estado e Sociedade, n. 46, p. 121-155, jan./jun. 2015. Disponível em: http://direitoestadosociedade.jur.puc-rio.br/media/Artigo5_46.pdf. Acesso em: 21 nov. 2019.

98 SCHAUER, Frederick. Has precedent ever really mattered in the Supreme Court? Georgia State University Law Review, vol. 24, n. 2, 2007, p. 399. Disponível em: https://heinonline.org/HOL/P?h=hein.journals/gslr24\&i=397. Acesso em: 22 nov. 2019.

99 V. FALCÃO, Joaquim; CERDEIRA, Pablo de Camargo; ARGUELHES, Diego Werneck. I Relatório Supremo em Números: O Múltiplo Supremo. Rio de Janeiro: FGV Direito Rio, 2011. Disponível em: http://hdl.handle.net/ 10438/10312. Acesso em: 22 nov. 2019.

100 VIEIRA, Oscar Vilhena. Supremocracia, op. cit., p. 457. 
BANKOWSKI, Zenon et al. Rationales for precedent. In: MACCORMICK, D. Neil; SUMMERS, Robert S. (Org.). Interpreting precedents: a comparative study. Aldershot: Ashgate/Dartmouth, 1997, p. 481-501.

BARBOZA, Estefânia Maria de Queiroz. Precedentes judiciais e segurança jurídica: fundamentos e possibilidades para a jurisdição constitucional brasileira. São Paulo: Saraiva, 2014.

BRASIL. Lei n 13.105, de 16 de março de 2015. Código de Processo Civil. Brasília, DF: Presidência da República, 16 mar. 2015. Disponível em: http://www.planalto.gov.br/ccivil_03/_ato2015-2018/2015/lei/ 113105.htm. Acesso em: 22 nov. 2019.

BRASIL. Superior Tribunal de Justiça (2. Turma). Recurso Especial n 1.367.549/ MG. Processo Civil. Administrativo. Ação Civil Pública. Obrigação de fazer. Dano Ambiental. Implementação de Obra Pública. Usina de Reciclagem de Resíduos Sólidos. Ingerência do Poder Judiciário. Violação do princípio da separação e poderes. Inexistência. Violação ao art. 333, I, do CPC caracterizada. Recorrente: Ministério Público do Estado de Minas Gerais. Recorrido: Município de Uberlândia. Relator: Min. Humberto Martins, 02 de setembro de 2014. Disponível em: https://ww2.stj.jus.br/websecstj/cgi/revista/REJ.cgi/ITA?seq=1299335\&tipo $=0 \&$ nreg $=201101325135 \&$ SeqCgrmaSessao $=\&$ CodOrgaoJgdr $=\& d t=20140908 \&$ formato=PDF $\&$ sal var=false. Acesso em: 21 nov. 2019.

BRASIL. Supremo Tribunal Federal (1. Turma). Mandado De Segurança 31.697/ DF. Ato do Conselho Nacional do Ministério Público. Competência reconhecida para fiscalizar os princípios que regem a administração pública, consagrados no Art. 37, caput, da Constituição Federal. Cessão de servidor público. Ausência dos pressupostos legais objetivos. Prevalência de interesse público sobre o privado. Impropriedade do debate. Impossibilidade de dilação probatória. Segurança indeferida Impetrante: Gustavo Henrique Cantenhe de Morgado e Outros. Impetrado: Presidente do Conselho Nacional do Ministério Público CNMP. Relator: Min. Dias Toffoli, 11 de março de 2014. Disponível em: http://redir.stf.jus.br/paginadorpub/ paginador.jsp?docTP=TP\&docID=5568219. Acesso em: 05 nov. 2019.

BRASIL. Supremo Tribunal Federal (1. Turma). Recurso Ordinário em Mandado de Segurança 26.071-1/ DF. Concurso Público. Candidato portador de deficiência visual. Ambliopia. Reserva de Vaga. Inciso VIII do art.37 da Constituição Federal. $\S 2^{\circ}$ do art. $5^{\circ}$ da Lei $n^{\circ}$ 8.11/90. Lei n $7.853 / 89$. Decretos n. ${ }^{\circ}$ s 3.298/99 e 5.296/2004. Recorrente: José Francisco de Araújo. Recorrido: Tribunal Superior do Trabalho. Relator: Min. Carlos Britto, 13 de novembro de 2007. Disponível em: http://redir.stf.jus.br/paginadorpub/paginador.jsp?docTP $=A C \& d o c I D=506599$. Acesso em: 21 nov. 2019

BRASIL. Supremo Tribunal Federal (plenário). Habeas Corpus 152.752/PR. Matéria Criminal. Execução Provisória da pena. Impetração em substituição a Recurso Ordinário constitucional. Cognoscibilidade. Ato reputado coator compatível com a jurisprudência do STF. llegalidade ou abuso de poder. Inocorrência. Alegado caráter não vinculante dos precedentes desta Corte. Irrelevância. Deflagração da etapa executiva. Fundamentação específica. Desnecessidade. Pedido expresso da acusação. Dispensabilidade. Plausibilidade de teses veiculadas em futuro Recurso Excepcional. Supressão de instância. Ordem denegada. Paciente: Luiz Inácio Lula da Silva. Impetrante: Cristiano Zanin Martins. Relator: Min. Edson Fachin, 04 de abril 2018. Disponível em: http://redir.stf.jus.br/paginadorpub/paginador.jsp?docTP=TP\&docID=15132272. Acesso em: 22 nov. 2019.

BRASIL. Supremo Tribunal Federal (plenário). Medida Cautelar Na Arguição De Descumprimento De Preceito Fundamental 378/ DF. ADPF 378 MC. Processo de Impeachment. Definição da legitimidade Constitucional do rito previsto na Lei № 1.079/1950. Adoção, como linha geral, das mesmas regras seguidas em 1992. Cabimento da ação e concessão parcial de medidas cautelares. Conversão em julgamento definitivo. Requerente: Partido Comunista do Brasil. Am. Curiae: Partido da Social Democracia BrasileiraPSDB e outros. Relator: Min. Edson Fachin. Relator do Acórdão: Min. Roberto Barroso, 17 de dezembro de 2015. Disponível em: http://redir.stf.jus.br/paginadorpub/paginador.jsp?docTP=TP\&docID=10444582. Acesso em: 05 nov. 2019. 
BUSTAMANTE, Thomas da Rosa de. Obiter dicta abusivos: esboço de uma tipologia dos pronunciamentos judiciais ilegítimos. Revista Direito GV, São Paulo, vol. 14, n.2, p.707-745, mai./ago. 2018. Disponível em: http://dx.doi.org/10.1590/2317-6172201827. Acesso em: 12 jul. 2019.

CANÁRIO, Pedro. Precedente usado por Janot em caso de impedimento contraria sua tese. Consultor Jurídico, 09 mai. 2017. Disponível em: https://www.conjur.com.br/2017-mai-09/alegar-suspeicao-gilmar-janot-usa-precedente contraria. Acesso em: 21 nov. 2019.

CENSURA a jornal se deve a discórdia entre ministros. Consultor Jurídico, 16 dez. 2009. Disponível em: https://www.conjur.com.br/2009-dez-16/censura-estadao-discordia-lei-imprensa. Acesso em: 12 nov. 2019. DIAS NETO, Theodomiro; BUENO, Cassio Scarpinella; FORGIONI, Paula. As áreas do direito e especificidades em matéria de pesquisa. In: NOBRE, Marcos et al. O que é pesquisa em Direito?, São Paulo: Quartier Latin, 2005, p. 173-186.

DUXBURY, Neil. The Nature and Authority of Precedent. Cambridge: CUP, 2008.

FALCÃO, Joaquim; CERDEIRA, Pablo de Camargo; ARGUELHES, Diego Werneck. I Relatório Supremo em Números: O Múltiplo Supremo. Rio de Janeiro: FGV Direito Rio, 2011. Disponível em: http://hdl.handle. net/ 10438/10312. Acesso em: 22 nov. 2019.

FARHANG, Sean; WAWRO, Gregory. Institutional Dynamics on the U.S. Court of Appeals: Minority Representation under Panel Decision Making. The Journal of Law, Economics \& Organization, vol. 20, n. 2, p. 299-330, out. 2004.

FERREIRA, Carolina Cutrupi; LANGENEGGER, Natalia; SILVA, Marina Jacob Lopes da. Construção de ementas das decisões do Supremo Tribunal Federal. FGV Direito SP Research Paper Series, São Paulo, n. 125, p. 1-17, jun. 2015. Disponível em: https://papers.ssrn.com/sol3/papers.cfm?abstract_id=2623294. Acesso em: 05 abr. 2018.

HART, H.L.A. The Concept of Law. 2. ed. New York: Oxford University Press, 1994.

HENDERSON, M. Todd. From seriatim to consensus and back again: A theory of dissent. The Supreme Court Review, vol. 2007, n. 1, p. 283-344, 2007. Disponível em: https://doi.org/10.1086/655172. Acesso em: 22 nov. 2019.

KLARMAN, Michael. Courts, Social Change, and Political Backlash. Philip A. Hart Memorial Lecture, n. 2, 2011. Disponível em: https://scholarship.law.georgetown.edu/cgi/viewcontent.cgi?article=1001\&contex$\mathrm{t}=$ hartlecture. Acesso em: 22 nov. 2019.

LEAL, Fernando. Uma jurisprudência que serve para tudo. Jota, em 12 mai 2015. Disponível em: www. jota.info/opiniao-e-analise/artigos/uma-jurisprudencia-que-serve-para-tudo-12052015. Acesso em: 21 nov 2019.

LEGALE, Siddharta. Superprecedentes. Revista Direito GV, São Paulo, vol. 12, n. 3, p. 810-845, set./dez. 2016. Disponível em: http://dx.doi.org/10.1590/ 2317-6172201633. Acesso em: 21 nov. 2019.

LEVENBOOK, Barbara. The meaning of a precedent. Legal Theory, vol. 6, n. 2, jun. 2000, p. 185-240.

MACCORMICK, D. Neil; SUMMERS, Robert S. (Org.). Interpreting precedents: a comparative study. Aldershot: Ashgate/Dartmouth, 1997.

MARSHALL, Geoffrey. What is binding in a precedent. In: MACCORMICK, D. Neil; SUMMERS, Robert S. (Org.). Interpreting precedents: a comparative study. Aldershot: Ashgate/Dartmouth, 1997, p. 503-517.

MAUÉS, Antônio M.. Jogando com os precedentes: regras, analogias, princípios. Revista Direito GV, vol. 16, n. 2, 2012, p. 587-623.

MELLO, Patrícia Perrone Campos; BARROSO, Luís Roberto. Trabalhando com uma nova lógica: a ascensão dos precedentes no direito brasileiro. Revista da AGU, vol. 15, n. 3, p. 9-52, jul./set. 2016. Disponível em: https://doi.org/10.25109/2525-328X.v.15.n.03.2016.854. Acesso em: 20 nov. 2019.

MENDES, Conrado Hübner. Lendo uma decisão: obiter dictum e ratio decidendi. Racionalidade e retórica na decisão. Sociedade Brasileira de Direito Público, p. 1-12, 2010. Disponível em: http://www.sbdp.org. 
br/arquivos/material/19_Estudo\%20dirigido\%20-\%20Ratio\%20decidendi\%20e\%20obter\%20dictum\%20 -\%20Conrado\%20Hubner\%20Mendes.pdf. Acesso em: 13 nov. 2019.

MITIDIERO, Daniel. Precedentes: da persuasão à vinculação. 3a. ed. São Paulo: Revista dos Tribunais, 2018. NOBRE, Marcos et al. 0 que é pesquisa em Direito?. São Paulo: Quartier Latin, 2005.

PARGENDLER, Mariana. The rise and decline of legal families. The American Journal of Comparative Law, vol. 60, n. 4, p. 1043-1074, out. 2012. Disponível em: http://www.jstor.org/stable/41721695. Acesso em: 21 nov. 2019.

PICININ, Graziela Maria. Informativo STF n ${ }^{345}$. Brasília: Supremo Tribunal Federal, $26-30$ abr. 2004. Disponível em: http://www.stf.jus.br/arquivo/informativo/documento/informativo345.htm. Acesso em: 22 nov. 2019.

PLENO - STF inicia julgamento de cabimento de embargos infringentes na AP 470 (1/2). [S.I.: s.n.], 2013. 1 Vídeo (1hr59min38s). Publicado pelo canal STF. Disponível em: https://youtu.be/TWy9wd18mfM. Acesso em: 12 nov. 2019.

SCHAUER, Frederick. Has precedent ever really mattered in the Supreme Court? Georgia State University Law Review, vol. 24, n. 2, p. 381-402, 2007. Disponível em: https://heinonline.org/HOL/P?h=hein.journals/ gslr24\&i=397. Acesso em: 22 nov. 2019.

SCHAUER, Frederick. Precedent. Stanford Law Review, vol. 39, n. 3, p. 571-605, fev. 1987.

SCHAUER, Frederick. Thinking like a lawyer: a new introduction to legal reasoning. Cambridge: Harvard University Press, 2009.

SEGAL, Jeffrey A.; SPAETH, Harold J. The influence of stare decisis on the votes of United States Supreme Court justices. American Journal of Political Science, vol. 40, n. 4, p. 971-1003, nov. 1996.

SILVA, Virgílio Afonso da. Deciding without deliberating. International Journal of Constitutional Law, vol. 11, n. 3, p. 557-584, 2013. Disponível em: https://doi.org/10.1093/icon/mot019 Acesso em: 21 nov. 2019.

SOUZA, André de; MARIZ, Renata; BRESCIANI, Eduardo. Rosa Weber nega habeas corpus a Lula, e deve ser rejeitado. $O$ Globo, Brasília, 04 abr. 2018. Disponível em: https://oglobo.globo.com/brasil/rosa-weber-nega-habeas-corpus-lula-pedido-deve-ser-rejeitado-22557114. Acesso em: 22 nov. 2019.

SUMERS, Robert. S. Precedent in the United States (New York State). In: MACCORMICK, D. Neil; SUMMERS, Robert S. (Org.). Interpreting precedents: a comparative study. Aldershot: Ashgate/Dartmouth, 1997, p. 355-406.

SUNSTEIN, Cass R. Legal reasoning and political conflict. New York: Oxford University Press, 1996.

SUPREMO TRIBUNAL FEDERAL. Emenda Regimental n², de 4 de dezembro de 1985. Altera os artigos 21, 67, 134, 169, 174, 181, 226, 228, 234, 235, 236, 239, 277, 325, 326, 327, 328, 329, 333, 355, 356, e 357 do Regimento Interno. Diário da Justiça: seção 1, Brasília, DF, p. 22717, 09 dez. 1985

TEIXEIRA, Matheus; FALCÃO, Márcio; CARNEIRO Luiz Orlando. Rosa Weber e os sinais trocados no julgamento do HC de Lula. Jota, 22 mar. 2018. Disponível em: https://www.jota.info/stf/rosa-weber-e-os-sinais-trocados-no-julgamento-do-hc-de-lula-22032018. Acesso em: 22 nov. 2019.

VIEIRA, Oscar Vilhena. Supremocracia. Revista Direito GV, São Paulo, vol. 4, n. 2, p. 441-464, jul./dez. 2008. Disponível em: http://bibliotecadigital.fgv.br/ojs/index.php/revdireitogv/article/view/35159/33964. Acesso em: 22 nov. 2019.

VOJVODIC, Adriana. Precedentes e argumentação no Supremo Tribunal Federal: entre a vinculação ao passado e a sinalização para o futuro. 2012. Tese (Doutorado em Direito) - Faculdade de Direito, Universidade de São Paulo, São Paulo, 2012. Disponível em: https://www.teses.usp.br/teses/disponiveis/2/2134/ tde-27092012-094000/publico/tese_Adriana_Vojvodic.pdf. Acesso em: 28 fev. 2020.

VOJVODIC, Adriana; MACHADO, Ana Mara França; CARDOSO, Evorah Lusci Costa. Escrevendo um romance, primeiro capítulo: precedentes e processo decisório no STF. Revista Direito GV, São Paulo, vol. 5, n. 1, p. 2144, jan./jun. 2009. Disponível em: http://www.scielo.br/pdf/rdgv/v5n1/a02v5n1. Acesso em: 21 nov. 2019. 